\title{
Ozone impacts of gas-aerosol uptake in global chemistry transport models
}

\author{
Scarlet Stadtler ${ }^{1}$, David Simpson ${ }^{2,3}$, Sabine Schröder ${ }^{1}$, Domenico Taraborrelli ${ }^{1}$, Andreas Bott ${ }^{4}$, and Martin Schultz ${ }^{1}$ \\ ${ }^{1}$ Institut für Energie- und Klimaforschung, IEK-8, Forschungszentrum Jülich, Jülich, Germany \\ ${ }^{2}$ EMEP MSC-W, Norwegian Meteorological Institute, Oslo, Norway \\ ${ }^{3}$ Dept. Space, Earth and Environment, Chalmers University of Technology, Gothenburg, Sweden \\ ${ }^{4}$ Meteorological Institute University Bonn, Bonn, Germany
}

Correspondence: David Simpson (david.simpson@met.no)

Received: 19 June 2017 - Discussion started: 3 July 2017

Revised: 21 December 2017 - Accepted: 10 January 2018 - Published: 5 March 2018

\begin{abstract}
The impact of six heterogeneous gas-aerosol uptake reactions on tropospheric ozone and nitrogen species was studied using two chemical transport models, the Meteorological Synthesizing Centre-West of the European Monitoring and Evaluation Programme (EMEP MSC-W) and the European Centre Hamburg general circulation model combined with versions of the Hamburg Aerosol Model and Model for Ozone and Related chemical Tracers (ECHAMHAMMOZ). Species undergoing heterogeneous reactions in both models include $\mathrm{N}_{2} \mathrm{O}_{5}, \mathrm{NO}_{3}, \mathrm{NO}_{2}, \mathrm{O}_{3}, \mathrm{HNO}_{3}$, and $\mathrm{HO}_{2}$. Since heterogeneous reactions take place at the aerosol surface area, the modelled surface area density $\left(S_{\mathrm{a}}\right)$ of both models was compared to a satellite product retrieving the surface area. This comparison shows a good agreement in global pattern and especially the capability of both models to capture the extreme aerosol loadings in east Asia.

The impact of the heterogeneous reactions was evaluated by the simulation of a reference run containing all heterogeneous reactions and several sensitivity runs. One reaction was turned off in each sensitivity run to compare it with the reference run. The analysis of the sensitivity runs confirms that the globally most important heterogeneous reaction is the one of $\mathrm{N}_{2} \mathrm{O}_{5}$. Nevertheless, $\mathrm{NO}_{2}, \mathrm{HNO}_{3}$, and $\mathrm{HO}_{2}$ heterogeneous reactions gain relevance particularly in east Asia due to the presence of high $\mathrm{NO}_{x}$ concentrations and high $S_{\mathrm{a}}$ in the same region. The heterogeneous reaction of $\mathrm{O}_{3}$ itself on dust is of minor relevance compared to the other heterogeneous reactions. The impacts of the $\mathrm{N}_{2} \mathrm{O}_{5}$ reactions show strong seasonal variations, with the biggest impacts on $\mathrm{O}_{3}$ in springtime when photochemical reactions are
\end{abstract}

active and $\mathrm{N}_{2} \mathrm{O}_{5}$ levels still high. Evaluation of the models with northern hemispheric ozone surface observations yields a better agreement of the models with observations in terms of concentration levels, variability, and temporal correlations at most sites when the heterogeneous reactions are incorporated. Our results are loosely consistent with results from earlier studies, although the magnitude of changes induced by $\mathrm{N}_{2} \mathrm{O}_{5}$ reaction is at the low end of estimates, which seems to fit a trend, whereby the more recent the study the lower the impacts of these reactions.

\section{Introduction}

Nitrogen species, ozone, and atmospheric aerosols are major pollutants in the atmosphere, having strong impacts on ecosystems and human health, and also interacting with climate (Ainsworth et al., 2012; Harrison and Yin, 2000; Simpson et al., 2014; IPCC, 2013). In regions where gas-phase and aerosol pollutants meet, heterogeneous chemistry can play a significant role (Jacob, 2000). The first heterogeneous process to become prominent in atmospheric chemistry was the heterogeneous destruction of stratospheric ozone on polar stratospheric clouds (Solomon et al., 1986; Solomon, 1999). However, heterogeneous processes are also relevant in the lower atmosphere, influencing tropospheric ozone and therefore oxidation capacity of the atmosphere (Ravishankara, 1997; Pöschl, 2005; Seinfeld and Pandis, 2012). An important example is the heterogeneous reaction of $\mathrm{N}_{2} \mathrm{O}_{5}$ on aerosols, which is known to impact the $\mathrm{NO}_{x}-\mathrm{O}_{3}$ cycle while 
mainly removing $\mathrm{NO}_{x}$ from the troposphere (Mozurkewich and Calvert, 1988; Dentener and Crutzen, 1993; Evans and Jacob, 2005; Chang et al., 2011; Brown and Stutz, 2012), which can lead to ozone reduction (Macintyre and Evans, 2010). Other oxidized nitrogen species also undergo heterogeneous reactions on different aerosol types. $\mathrm{NO}_{2}, \mathrm{HNO}_{3}$, and $\mathrm{NO}_{3}$ react on wet surfaces of different aerosol types and increase aerosol nitrate content (Rudich et al., 1998; Goodman et al., 1999). $\mathrm{HNO}_{3}$ reacts also with dust and sea salt particles which is again a sink for $\mathrm{NO}_{x}$ and a source for particulate nitrate (Davies and Cox, 1998; Hanisch and Crowley, 2001). Moreover, heterogeneous reaction of $\mathrm{NO}_{2}$ produces $\mathrm{HONO}$ which plays the role of a reservoir specie for NO and OH production (Platt et al., 1980). Other species also undergo heterogeneous reactions. $\mathrm{O}_{3}$ reacts on dust particles and this has been estimated to lead to an ozone loss of about $20 \%$ in dusty regions (Usher et al., 2003). $\mathrm{HO}_{2}$ reacts on wet particles leading to $\mathrm{H}_{2} \mathrm{O}_{2}$ production (Thornton and Abbatt, 2005). Furthermore, heterogeneous reactions lead to halogen release from sea salt aerosols (Frenzel et al., 1998; Yang et al., 2008; Lowe et al., 2011). Many modelling studies have been conducted over the years on these processes, but usually heterogeneous reactions were studied individually, and typically considering annual global budgets rather than detailed temporal or spatial resolution of the impacts (Dentener and Crutzen, 1993; Rudich et al., 1998; Saathoff et al., 2001; Bauer et al., 2004; Hodzic et al., 2006; Thornton et al., 2008; Chang et al., 2011).

This paper presents estimates of the global impact of heterogeneous reactions of $\mathrm{N}_{2} \mathrm{O}_{5}, \mathrm{NO}_{3}, \mathrm{NO}_{2}, \mathrm{HNO}_{3}, \mathrm{HO}_{2}$, and $\mathrm{O}_{3}$ and evaluates each reaction in a systematic way. The influence of each reaction on the magnitude and spatial and temporal variations in surface ozone is illustrated. The greatest impacts are seen in northern hemispheric regions of North America, Europe, south Asia, and east Asia. The $\mathrm{N}_{2} \mathrm{O}_{5}$ reaction is shown to significantly affect the spring peak of surface $\mathrm{O}_{3}$ at sites in all these regions.

Section 2 presents the two global-scale chemical transport models, the Meteorological Synthesizing Centre-West of the European Monitoring and Evaluation Programme (EMEP MSC-W) and the European Centre Hamburg general circulation model combined with versions of the Hamburg Aerosol Model and Model for Ozone and Related chemical Tracers (ECHAM-HAMMOZ), as well as details of the reaction parameterizations and sensitivity tests. In Sect. 3, a short review of the range of reaction probabilities for each heterogeneous reaction is given. Model setups and sensitivity runs are described in Sect. 4. Section 5 first presents a comparison of the simulated surface area from the models with satellite-derived products, since the surface area of aerosols is crucial for heterogeneous chemistry. Especially in polluted regions, where high trace gas concentrations meet large surface areas provided by aerosols, heterogeneous chemistry might be of significant importance explaining aerosol composition and trace gas mixing ratios (Jacob, 2000; Pathak et al., 2009). Section 5 also presents the results of the sensitivity tests and comparisons of daily maximum ozone time series for 2012 with surface station observations for selected sites. In Sect. 5.4, we discuss these results compared to previous studies, as well as comment on a number of open questions concerning heterogeneous reactions. Finally, Sect. 6 summarizes the results and implications for atmospheric chemistry.

\section{Model description}

Two models, the chemical transport model EMEP MSC-W (v4.16) (Simpson et al., 2012, 2017) and the global chemistry aerosol climate model ECHAM6.3-HAM2.3MOZ1.0 (Schultz et al., 2018) were used to study the heterogeneous chemistry of various compounds in the atmosphere.

\subsection{EMEP}

The basis of the EMEP MSC-W chemical transport model has been described in detail by Simpson et al. (2012), but substantial updates have been made in the treatment of aerosols, biogenic emissions, and chemistry in recent years. Simpson et al. $(2015,2017)$ have documented the main changes in aerosol surface area and biogenic volatile organic compound (VOC) emissions as discussed below, up to version rv4.15. The model version used in this report, rv4.16, is the latest version of the model. The main changes in rv4.16 have been the inclusion of the dry and wet deposition for $\mathrm{N}_{2} \mathrm{O}_{5}$, using the same rates as for $\mathrm{HNO}_{3}$, and the implementation of an improved radiation scheme, based upon Weiss and Norman (1985). These changes have not affected basic model performance very much compared to previous publications, but of course the concentrations of $\mathrm{N}_{2} \mathrm{O}_{5}$ and its impact on ozone are reduced somewhat compared to earlier model versions. The EMEP model code is open-source and is available at https://github.com/metno/emep-ctm.

The default model setup includes 20 vertical layers up to $100 \mathrm{hPa}$, using terrain-following coordinates, and the lowest layer has a thickness of about $90 \mathrm{~m}$. Although originally designed for European applications (previously using a grid of resolution $50 \mathrm{~km}$, more recently $28 \mathrm{~km}$ ), the model is very flexible and is now applied on scales ranging from global (Jonson et al., 2010) to local (1-7 km grids), e.g. Vieno et al. (2010, 2014); Schaap et al. (2015). Anthropogenic emissions from land-based sources are here taken from the so-called PANHAM database from the EU PANDA project (http://panda-project.eu), which combined emissions from the global Task Force on Hemispheric Transport of Air Pollution (HTAP) database (http://edgar.jrc.ec.europa.eu/htap_v2/ index.php?SECURE=123) with the Multi-resolution Emission Inventory for China (MEIC) database (http://www. meicmodel.org/).

Emissions of VOCs from biogenic sources are calculated in the model based upon land cover and meteorolog- 
ical conditions. Emission factors for earlier versions of the EMEP model were mainly intended for European simulations (Simpson et al., 1999, 2012), but during 2016-2017 the factors used in non-European areas were substantially revised - see Simpson et al. (2017) for details. For details of other emissions (soil NO, lightning, aircraft, biomass burning), see Simpson et al. (2012). For the present study, meteorological data from the European Centre for Medium Range Weather Forecasts Integrated Forecasting System (ECMWF-IFS) model (https://www.ecmwf.int/en/research/ modelling-and-prediction) were used, and the model runs with $1^{\circ} \times 1^{\circ}$ latitude-longitude resolution.

The chemical scheme in the EMEP MSC-W model, denoted "EmChem16", consists of a standard gas-phase mechanism (132 species, 183 reactions, a recent update of the earlier EmChem03 evaluated by Andersson-Sköld and Simpson, 1999), extended with organic aerosols using a volatilitybasis-set scheme (Bergström et al., 2012; Simpson et al., 2012), plus sea salt (Tsyro et al., 2011) and dust aerosol. Unlike ECHAM-HAMMOZ, the EMEP model includes $\mathrm{NH}_{3}$ and handles the resulting interactions with sulfate, $\mathrm{HNO}_{3}$, and ammonium nitrate through the use of the MARS equilibrium solver (Binkowski and Shankar, 1995). Unfortunately, interactions with sea salt have not yet been implemented in EMEP-MARS. The chemical equations are solved using the TWOSTEP algorithm (Verwer and Simpson, 1995; Verwer et al., 1996).

The EMEP MSC-W model has been extensively compared with measurements of many different compounds with generally good performance (e.g. Simpson et al., 2006a, b; Fagerli and Aas, 2008; Aas et al., 2012; Gauss et al., 2011), although most of these studies have focused on Europe. Still, in comparisons with global data and other models, the EMEP MSC-W model seems to perform well, especially more recent versions (Jonson et al., 2010, 2015; Angelbratt et al., 2011; Bian et al., 2017).

As of EMEP MSC-W model version rv4.7 (Simpson et al., 2015), aerosol surface area $\left(S_{\mathrm{a}}\right)$ is estimated using the empirical relations of Gerber (1985), which simply requires aerosol mass concentrations and assumed aerosol density and size parameters. Values of $S_{\mathrm{a}}$ are calculated for fine and coarse particulate matter $\left(\mathrm{PM}_{\mathrm{f}}, \mathrm{PM}_{\mathrm{c}}\right)$ both as totals (including all components for Reactions R1-R3 and R5 in Table 1) and separately for coarse sea salt and dust particles - which we denote as $S_{\mathrm{ss}}$ and $S_{\mathrm{du}}$, respectively. The distinction between total area $S_{\mathrm{a}}$ and $S_{\mathrm{ss}}$ and $S_{\mathrm{du}}$ was made to allow the use of Gerber's specific parameterizations for sea salt and dust for Reactions (R5) and (R6) (Table 1), with the assumption that where concentrations are large (e.g. over oceans, deserts), these give a better estimate of $S_{\mathrm{a}}$ than the rural parameterization would give. Further, for $S_{\text {du }}$ the aerosol is assumed to be dry, which is not always true but is intended to reflect the nature of desert-dust-dominated aerosol. The EMEP model does not include fine-mode formation of $\mathrm{NO}_{3}^{-}$ through Reaction (R4), since the relationship between $\mathrm{HNO}_{3}$ and fine-mode nitrate is given by the thermodynamic equilibrium solver MARS.

\subsection{ECHAM-HAMMOZ}

ECHAM-HAMMOZ is an aerosol chemistry-climate model capable of performing interactive aerosol chemistry simulations. For this study, simulations were done using version ECHAM6.3-HAM2.3MOZ1.0 (https://redmine.hammoz. ethz.ch/projects/hammoz/wiki/Echam630-ham23-moz10). The model system ECHAM-HAMMOZ consists of the general circulation model ECHAM6.3 (Stevens et al., 2013), the aerosol model HAM2.3 (Neubauer et al., 2018; Zhang et al., 2012) and the chemistry model MOZ1.0 (Schultz et al., 2018). ECHAM calculates meteorological variables, cloud processes, and radiative transfer considering greenhouse gases and aerosols. The simulations in this study use hybrid sigma coordinates with 47 vertical layers, while the surface layer thickness is about $50 \mathrm{~m}$. The horizontal resolution T63 leads to an associated $1.875^{\circ} \times 1.875^{\circ}$ Gaussian grid.

HAM simulates the evolution of aerosols considering aerosol and aerosol precursor emissions, microphysical processes as nucleation, coagulation, accumulation, sedimentation, and dry and wet deposition. Via direct and indirect aerosol effects a feedback to climate system is simulated (Neubauer et al., 2018). The aerosols in HAM are assumed to be internally mixed and consist of up to five components: sulfate, sea salt, dust, organic carbon, and black carbon. To describe the aerosol number, the microphysical driver M7 uses a distribution of seven log-normal functions describing four wet aerosol modes and three dry aerosol modes. Hence, the wet functions cover nucleation, Aitken, accumulation, and coarse modes and the dry functions do not cover the nucleation mode. The height and median radius of the distribution are calculated; just its width is fixed. Due to aerosol aging, it is possible for insoluble particles to become soluble (Vignati et al., 2004). Dust and sea salt emissions are interactively calculated considering the wind speed at $10 \mathrm{~m}$. Dimethyl sulfate emissions are parametrized and emissions of sulfate dioxide, sulfate aerosol, black carbon, and organic carbon are taken from the Representative Concentration Pathway (RCP) 8.5 emissions (Van Vuuren et al., 2011). Finally, optical properties of the aerosol are calculated and impact the atmospheric circulation in ECHAM (Zhang et al., 2012).

Atmospheric chemistry is simulated by MOZ which is based on the Model for Ozone and Related chemical Tracers version 3.5 (MOZART3.5) (Stein et al., 2012), connecting tropospheric chemistry of MOZART4 (Emmons et al., 2010) and stratospheric chemistry of MOZART3 (Kinnison et al., 2007). Further development since Stein et al. (2012) led to MOZ being a chemical mechanism resembling to CAM-chem (Community Atmosphere Model with Chemistry) (Lamarque et al., 2012) with several revisions, extended chemistry of aromatic compounds, and a more detailed isoprene chemistry based on Taraborrelli et al. (2009). 
The version MOZ1.0 used here consists of 242 tracers, 733 chemical reactions which contain 142 photolysis reactions, 6 heterogeneous tropospheric reactions, and 16 stratospheric heterogeneous reactions. Further, MOZ calculates dry and wet deposition of gases. Anthropogenic emissions are taken from the emission inventory RCP8.5 (Van Vuuren et al., 2011). Biogenic emissions of $\mathrm{VOC}$ and $\mathrm{NO}_{2}$ are calculated interactively by MEGAN (Model of Emissions of Gases and Aerosols from Nature) (Guenther et al., 2006; Henrot et al., 2017). NO lightning emission are parametrized as described by Grewe et al. (2001).

HAM and MOZ interact via two physical processes. First, assuming spherical aerosols, the surface area density for heterogeneous reactions is calculated using aerosol distribution and median radius. Second, MOZ provides fields of oxidants for aerosol formation from gas-phase precursors. The HAMMOZ coupling does not include ammonium nitrate formation due to the lack of nitrate aerosol in the current HAM version. Therefore, reactive uptake of nitric acid leads to a total loss, based on the assumption of a quick loss of gas-phase $\mathrm{HNO}_{3}$ and particulate nitrate. To underline, heterogeneous reactions in ECHAM-HAMMOZ do not form $\mathrm{HNO}_{3}$ in the gas phase but introduce a direct loss to the products $\mathrm{HNO}_{3}$ and $\mathrm{NO}_{3}^{-}$.

\section{Heterogeneous reactive uptake}

Experimental studies show that oxidized nitrogen species, ozone, and the hydroperoxy radical undergo heterogeneous reactions on wet and dry aerosols. Heterogeneous reactions can be modelled as a pseudo-first-order process (Ammann et al., 2013).

$\frac{\mathrm{d}[\mathrm{X}]_{\mathrm{g}}}{\mathrm{d} t}=-k_{\mathrm{X}}[\mathrm{X}]_{\mathrm{g}}$

The change in gas-phase concentration of the species $\mathrm{X}=\mathrm{N}_{2} \mathrm{O}_{5}, \mathrm{NO}_{3}, \mathrm{NO}_{2}, \mathrm{HNO}_{3}, \mathrm{HO}_{2}, \mathrm{O}_{3}$ is proportional to its gas-phase concentration $[\mathrm{X}]_{\mathrm{g}}$ and a reaction rate coefficient $k_{\mathrm{X}}$ (Schwartz, 1986):

$k_{\mathrm{X}}=\left(\frac{r_{\mathrm{p}}}{D_{\mathrm{g}}}+\frac{4}{c_{\mathrm{X}} \cdot \gamma_{\mathrm{X}}}\right)^{-1} S_{\mathrm{a}}$,

where $D_{\mathrm{g}}$ represents the gas-phase diffusion coefficient, $r_{\mathrm{p}}$ is the particle radius, $c_{\mathrm{X}}$ is the mean molecular velocity of the species $\mathrm{X}, \gamma_{\mathrm{X}}$ represents the reaction probability, and $S_{\mathrm{a}}$ is the surface area density. The $\gamma_{\mathrm{X}}$ values are generally determined from laboratory measurements. The first term in Eq. (2) is very small for particles of accumulation mode and larger, and is neglected in the EMEP model. The main challenges for chemistry transport models are the calculation of a proper surface area density $\left(S_{\mathrm{a}}\right)$ and the parameterization of the reaction probability $\gamma_{\mathrm{X}}$.

First, Table 1 summarizes the heterogeneous reactions investigated in this study. Second, Sect. 3.1-3.6 discuss literature values of $\gamma$ associated with each reaction. An overview
Table 1. Heterogeneous reactions in the EMEP MSC-W and ECHAM-HAMMOZ models. The second column specifies the aerosol type on which the reaction proceeds in the models. SS: sea salt, DU: dust, PM: particulate matter.

\begin{tabular}{lllll}
\hline No. & Reaction & & $\begin{array}{l}\text { Aerosol } \\
\text { type }\end{array}$ & Notes \\
\hline (R1) & $\mathrm{N}_{2} \mathrm{O}_{5}$ & $\rightarrow 2 \mathrm{HNO}_{3}$ & $\mathrm{PM}$ & 1 \\
$(\mathrm{R} 2)$ & $\mathrm{NO}_{3}$ & $\rightarrow \mathrm{HNO}_{3}$ & $\mathrm{PM}$ & 2 \\
$(\mathrm{R} 3)$ & $\mathrm{NO}_{2}$ & $\rightarrow 1 / 2 \mathrm{HNO}_{3}+1 / 2 \mathrm{HONO}$ & $\mathrm{PM}$ & 2 \\
$(\mathrm{R} 4)$ & $\mathrm{HNO}_{3}$ & $\rightarrow \mathrm{NO}_{3}^{-}$ & $\mathrm{SS}, \mathrm{DU}$ & 2,3 \\
$(\mathrm{R} 5)$ & $\mathrm{HO}_{2}$ & $\rightarrow 1 / 2 \mathrm{H}_{2} \mathrm{O}_{2}$ & $\mathrm{PM}$ & 2 \\
$(\mathrm{R} 6)$ & $\mathrm{O}_{3}$ & $\rightarrow \mathrm{HO}_{2}$ & $\mathrm{DU}$ & \\
\hline
\end{tabular}

${ }^{1}$ Just for RH $>40 \%$ in EMEP. ${ }^{2}$ Just on wet aerosol in ECHAM-HAMMOZ. ${ }^{3}$ Just on coarse-mode dust and sea salt in EMEP using $S_{\mathrm{ss}}$ and/or $S_{\mathrm{du}}$; see Sect. 2.1.

of the parameterization and values used for the different reaction probabilities is given in Table 2. ECHAM-HAMMOZ and EMEP MSC-W use the same reaction probabilities or functions for many reactions, with the most important difference being the lack of ammonium nitrate aerosol in ECHAM-HAMMOZ. Lastly, to check if the surface area density is realistic, simulated $S_{\mathrm{a}}$ is compared to a satellite model product in Sect. 5.1.

\section{1 $\quad \mathrm{N}_{2} \mathrm{O}_{5}$}

$\mathrm{N}_{2} \mathrm{O}_{5}$ reaction probability depends on aerosol water content and aerosol composition. Therefore, several laboratory studies measured $\gamma$ values on different aerosol types leading to the possibility to derive detailed parameterizations (Riemer et al., 2003, 2009; Evans and Jacob, 2005; Liao and Seinfeld, 2005; Davis et al., 2008; Bertram and Thornton, 2009; Griffiths et al., 2009; Brown and Stutz, 2012). For dry sulfate aerosol, reaction probabilities range between $10^{-4}$ and $10^{-3}$; for wet aerosol, $\gamma$ ranges between $10^{-3}$ and $8.6 \times 10^{-2} \mathrm{de}-$ pending on relative humidity. The $\mathrm{N}_{2} \mathrm{O}_{5}$ heterogeneous reaction humidity dependence also explains the range of reaction probabilities of sea salt aerosol of $6 \times 10^{-3}$ to $4 \times 10^{-2}$. On nitrate containing aerosol, lower reaction probabilities were found due to nitrate effect (Wahner et al., 1998) between $3 \times 10^{-4}$ and $3 \times 10^{-3}$ (Chang et al., 2011, and references therein). Moreover, $\mathrm{N}_{2} \mathrm{O}_{5}$ can react on organic aerosol under dry conditions with low reaction probabilities on the order of $10^{-6}$ and $10^{-5}$ (Gross et al., 2009). This value increases to $10^{-4}-10^{-3}$ under wet conditions, because the higher water content allows $\mathrm{N}_{2} \mathrm{O}_{5}$ to hydrolyse (Thornton et al., 2003). Even dust aerosols can be covered by a layer of water leading to a reaction probability between $3 \times 10^{-3}$ at $30 \%$ and $2 \times 10^{-2}$ at $70 \%$ relative humidity (Bauer et al., 2004). For $\mathrm{N}_{2} \mathrm{O}_{5}$ reaction on black carbon, Sander et al. (2006) reported a wide range of reaction probabilities between $2 \times 10^{-2}$ and $10^{-6}$. 
Table 2. Reaction probabilities for the different species. Unless explicitly labelled (in parentheses after the equation), both models use the same formulation. Here, RH denotes relative humidity in range, $\mathrm{RH} \in(0,100)$, and $\mathrm{fRH}$ denotes fractional relative humidity in range, $\mathrm{fRH} \in(0,1)$.

\begin{tabular}{lll}
\hline Specie & $\gamma$ & Reference \\
\hline $\mathrm{N}_{2} \mathrm{O}_{5}$ & $\gamma_{\mathrm{SS}}= \begin{cases}0.005, \mathrm{RH} \leq 62 \% \\
0.03, \mathrm{RH} \geq 62 \%\end{cases}$ & EVA05 \\
& $\gamma_{\mathrm{SU}}=\alpha \times 10^{-\beta}$ & EVA05 \\
& $\alpha=2.79 \times 10^{-4} \mathrm{fRH}+1.3 \times 10^{-4} \mathrm{fRH}-3.43 \times 10^{-6} \mathrm{fRH}^{2}+7.52 \times 10^{-8} \mathrm{fRH}^{3}$ & \\
& $\beta=\left\{\begin{array}{l}4 \times 10^{-2}(T-294), T>282 \mathrm{~K} \\
-0.48, T \leq 282 \mathrm{~K}\end{array}\right.$ & \\
& $\gamma_{\mathrm{DU}}=0.01(\mathrm{EMEP})$ & EVA05 \\
& $\gamma_{\mathrm{DU}}=4.25 \times 10^{-4} \mathrm{RH}-9.75 \times 10^{-3}(30 \% \leq \mathrm{RH} \leq 70 \%)($ ECHAM $)$ & LIA05 \\
& $\gamma_{\mathrm{OC}}= \begin{cases}0.03, \mathrm{RH}>57 \% \\
5.2 \times 10^{-2}, \mathrm{RH} \leq 57 \%\end{cases}$ & \\
& $\gamma_{\mathrm{BC}}=0.005$ & EVA05 \\
& $\gamma_{\mathrm{AN}}=\min (0.0154,1 /(1+\exp (8.10774-0.04902 \cdot \mathrm{RH})))($ EMEP $)$ & DAV08 \\
& $\gamma_{\mathrm{SIA}}=f_{\mathrm{SU}} \gamma_{\mathrm{SU}}+\left(1-f_{\mathrm{SU}}\right) \gamma_{\mathrm{AN}}($ EMEP $)$ & SIM15 \\
$\mathrm{NO}_{3}$ & $\gamma_{\text {where }} f_{\mathrm{SU}}$ is the mass fraction of sulfate in inorganic aerosol; see Sect. 3.1) $)$ & \\
$\mathrm{NO}_{2}$ & $\gamma=10^{-4}$ & JAC00 \\
$\mathrm{HNO}_{3}$ & $\gamma_{\mathrm{SS}}=0.01$ & JAC00 \\
$\mathrm{HO}_{2}$ & $\gamma_{\mathrm{DU}}=0.1$ & DAV98 \\
$\mathrm{O}_{3}$ & $\gamma_{\mathrm{DU}}=0.2$ & HOD06 \\
\hline
\end{tabular}

The subscripts refer to the aerosol compounds as given in Table 1, plus OC: organic carbon/organic matter; SU: sulfate; SIA: secondary inorganic aerosol; BC: black carbon. Refs: DAV98: Davies and Cox (1998). DAV08: Davis et al. (2008). EVA05: Evans and Jacob (2005). JAC00: Jacob (2000). LIA05: Liao and Seinfeld (2005). HOD06: Hodzic et al. (2006). NIC09: Nicolas et al. (2009). SIM15: Simpson et al. (2015).

Most studies have used laboratory data to estimate $\gamma$ values, but some have made use of ambient data. Brown et al. (2009) used aircraft measurements over Texas and found observation-based $\gamma$ values of approximately $5 \times 10^{-4}-6 \times$ $10^{-3}$, usually substantially lower (often a factor of 10 ) than values calculated using laboratory-based values. Using aircraft measurements around the UK, Morgan et al. (2015) found rather high $\gamma$ values for $\mathrm{N}_{2} \mathrm{O}_{5}$, from approximately $1 \times 10^{-2}-3 \times 10^{-2}$, with strong dependencies on sulfate, and a clear suppression of $\gamma$ due to nitrate. They concluded that including the suppressive effect of organic aerosol in the uptake parameterization leads to significant underprediction of the $\gamma$ values. Further, direct $\mathrm{N}_{2} \mathrm{O}_{5}$ measurements retrieved a high daily variation of $\gamma_{\mathrm{N}_{2} \mathrm{O}_{5}}$ also explained by the nitrate effect leading to a mean value of $5.4 \times 10^{-3}$ ranging from $3 \times 10^{-5}$ to $2.9 \times 10^{-2}$ (Riedel et al., 2012). In Stone et al. (2014) and Wagner et al. (2013), in situ measurements of $\mathrm{N}_{2} \mathrm{O}_{5}$ were used to retrieve the reaction probability within the framework of a box model. In Stone et al. (2014), $\gamma_{\mathrm{N}_{2} \mathrm{O}_{5}}$ is varied over a range of values between 0 and 1 , and they found that values of $2 \times 10^{-1}-2 \times 10^{-2}$ agreed best with observations. Wagner et al. (2013) retrieved the reaction probability of $\mathrm{N}_{2} \mathrm{O}_{5}$ using a box model driven by ambient wintertime observations. The reaction probability distribution ranges between $2 \times 10^{-3}$ and $1 \times 10^{-1}$, displaying a maximum at $2 \times 10^{-2}$.

It is clear from the studies mentioned above that great uncertainties surround both the magnitude and the chemical dependence of $\gamma$ values for $\mathrm{N}_{2} \mathrm{O}_{5}$. Even thorough evaluations such as those of Davis et al. (2008) or Chang et al. (2011) have little consideration of important components of the aerosol such as organic matter, and even such schemes seem to be inconsistent with the aircraft observations discussed above. For our modelling studies, we have not tried to develop or use yet another scheme, but rather to make use of the $\gamma$ schemes already implemented in each model, with some small efforts at harmonization to build similar reference schemes.

The equations used for EMEP MSC-W and ECHAMHAMMOZ can be found in Table 2. Both models make extensive use of the parameterizations developed by Evans and Jacob (2005), with the largest difference being that EMEP includes ammonium nitrate (in fine particles) among the nitrate species. For $\mathrm{N}_{2} \mathrm{O}_{5}$, the uptake coefficients for sulfate, sea salt, and organic aerosol are identical in the two models. For the reaction on dust, both models rely on Bauer et al. (2004) which was interpreted differently by Evans and Jacob (2005) and Liao and Seinfeld (2005). This small difference 

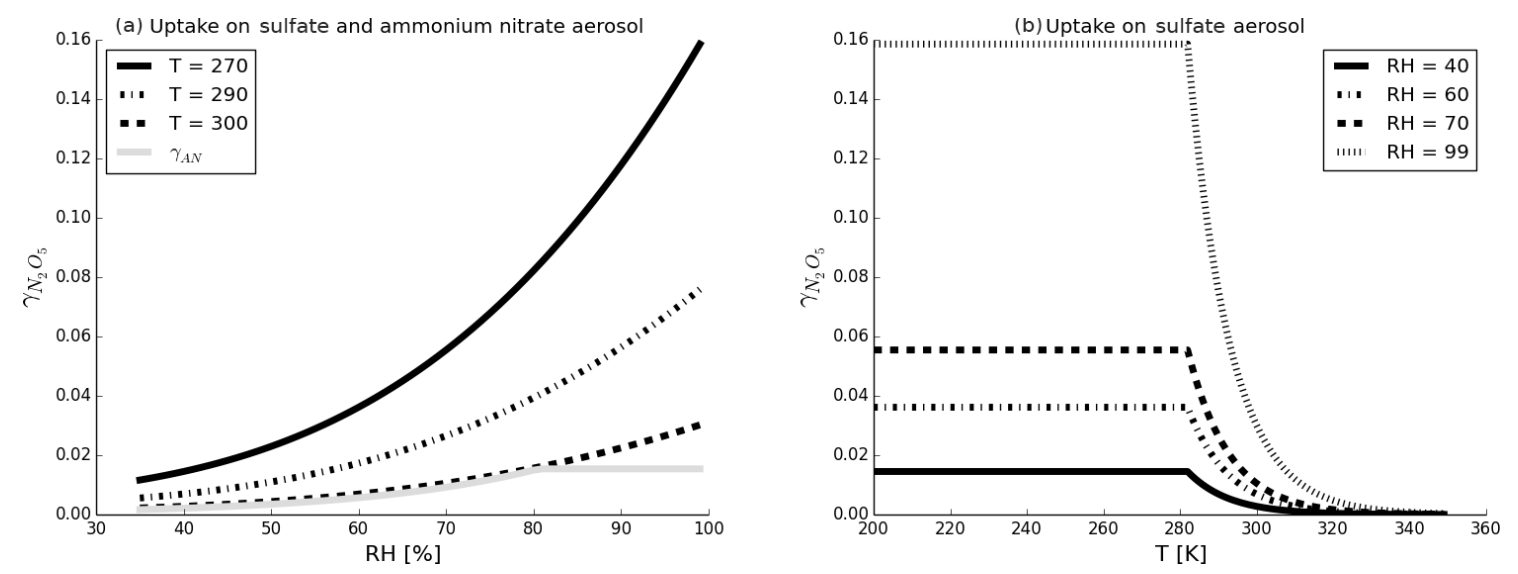

Figure 1. (a) $\mathrm{N}_{2} \mathrm{O}_{5}$ reaction probability dependence on relative humidity for sulfate (black) and nitrate (grey) aerosol. For sulfate aerosol, three temperatures are shown. (b) $\mathrm{N}_{2} \mathrm{O}_{5}$ reaction probability temperature dependence on sulfate aerosol for four relative humidities. Parameterizations are from Evans and Jacob (2005) and Davis et al. (2008); see text.

in the uptake coefficient formulation on dust does not lead to large differences in the resulting uptake coefficient.

EMEP MSC-W also modifies the $\gamma$ value for secondary inorganic aerosol to account for a nitrate inhibition effect (Wahner et al., 1998; Riemer et al., 2003). This makes use of the $\gamma_{\mathrm{AN}}$ factor presented in Davis et al. (2008) for ammonium nitrate and is merged with the sulfate factor in a manner reminiscent of Riemer et al. (2003). First, a sulfate mass fraction within the secondary inorganic aerosol (SIA) is calculated, $f_{\mathrm{SU}}=m_{\mathrm{SO}_{4}} /\left(m_{\mathrm{SO}_{4}}+m_{\mathrm{NO}_{3}}\right)$; then, $\gamma_{\mathrm{SIA}}$ is calculated as given in Table 2 .

Figure 1 illustrates the $\gamma$ values for sulfate aerosol from Evans and Jacob (2005) as a function of relative humidity (RH) and temperature for sulfate, and the RH dependency of $\gamma$ for nitrate from the Davis et al. (2008) formulation. The negative temperature dependence after $280 \mathrm{~K}$ can be explained by increasing volatility with increasing temperature leading to less uptake on the aerosol. As described before, reaction probability increases with increasing water content in the aerosol due to enhanced $\mathrm{N}_{2} \mathrm{O}_{5}$ hydrolysis. Even at high $\mathrm{RH}$, reaction probability on nitrate containing aerosol is not as high as on sulfate aerosol. Nevertheless, the very high $\gamma$ values found at high RH seem questionable, because the aerosol itself becomes saturated at high RH and these small water content changes should not have such a huge impact on the heterogeneous reaction.

No further parameterization considering organic coatings is used in either EMEP MSC-W or ECHAM-HAMMOZ due to the large uncertainties in this effect (e.g. Brown et al., 2009; Morgan et al., 2015) and the fact that ambient organic matter $(\mathrm{OM})$ and its thermodynamic properties are so poorly understood (Hallquist et al., 2009). Further, sensitivity runs done with ECHAM-HAMMOZ have shown minor global impact of organic coatings (Stadtler, 2015). Figure S1 in the Supplement illustrates the $\gamma_{\mathrm{N}_{2}} \mathrm{O}_{5}$ values from the two models using the setups described in Sect. 4, showing values of around 0.01-0.04 over much of the globe.

\section{$\begin{array}{lll}3.2 & \mathrm{NO}_{3}\end{array}$}

The nitrate radical $\mathrm{NO}_{3}$ undergoes hydrolysis in wet aerosols, but was also observed to react with organic compounds on the aerosol surface. Hydrolysis of nitrate radicals $\mathrm{NO}_{3}$ happens on various aerosol types depending on the water content. $\mathrm{NO}_{3}$ heterogeneous reaction produces $\mathrm{HNO}_{3}$ and $\mathrm{OH}$ in the aqueous particle phase and can be counted as a $\mathrm{NO}_{x}$ sink (Rudich et al., 1998). Several laboratory studies have shown $\gamma$ ranging between $10^{-4}$ and $10^{-3}$ (Rudich et al., 1996; Moise et al., 2002). Jacob (2000) recommended to use $\gamma=10^{-3}$ for atmospheric chemistry model simulations.

Reactions with different organic compounds were explored in laboratory experiments. Gross and Bertram (2008) measured the reaction probabilities between 0.059 and 0.79 of $\mathrm{NO}_{3}$ with different polycyclic aromatic hydrocarbons leading to $\mathrm{NO}_{2}$ and $\mathrm{HNO}_{3}$ formation. Two following studies also found high reaction probabilities of $\mathrm{NO}_{3}$ with alkenoic acid (>0.07) (Gross et al., 2009) and alkene monolayers (0.034) (Gross and Bertram, 2009). Organic coatings could enhance $\mathrm{NO}_{3}$ reactive uptake; nevertheless, knowledge of explicit organic compounds in the organic fraction of aerosol is unknown in both models' systems. Therefore, the recommended $\gamma=10^{-3}$ for $\mathrm{NO}_{3}$ hydrolysis value was adopted for EMEP and ECHAM-HAMMOZ.

\section{3 $\mathrm{NO}_{2}$}

$\mathrm{NO}_{2}$ heterogeneous reaction leads to the production of $\mathrm{HNO}_{3}$ and HONO. Especially in humid environments, the heterogeneous reaction may account for up to $95 \%$ of HONO production (Goodman et al., 1999). During nighttime, HONO can accumulate in the atmosphere and therefore be an efficient $\mathrm{OH}$ radical source during the morning when 
sunrise starts photolysis (Goodman et al., 1999). Estimates of $\gamma$ for $\mathrm{NO}_{2}$ vary widely, however, with several laboratory studies giving a range between $10^{-8}$ and $10^{-3}$ (Harrison and Collins, 1998; Kleffmann et al., 1998; Arens et al., 2001; Underwood et al., 2001). Jacob (2000) recommended $\gamma=10^{-4}$ and this value is used for this study.

\section{$3.4 \mathrm{HNO}_{3}$}

Nitric acid reacts on sea salt and dust aerosol surfaces, producing nitrate which stays in the aerosol phase (Davies and Cox, 1998; Hodzic et al., 2006). Experimentally derived $\gamma$ values for $\mathrm{HNO}_{3}$ on sea salt range between $10^{-4}$ and $10^{-2}$ (Davies and Cox, 1998, and references therein). A relative-humidity-dependent uptake coefficient was proposed in Hauglustaine et al. (2014) for increasing $\gamma$ from $10^{-3}$ and $10^{-1}$ to cover low and high relative humidity. No such relative humidity dependence was used in this study, because for the conditions in the marine boundary layer, the value of $10^{-2}$ fits well and is used here.

Heterogeneous reaction of $\mathrm{HNO}_{3}$ on dust was studied on different types of minerals, atmospheric dust types, and for a range of relative humidities giving $\gamma$ in the range of $10^{-6}$ and $10^{-1}$ (Hanisch and Crowley, 2001; Usher et al., 2003; Liu et al., 2008; Hauglustaine et al., 2014). Although in Fairlie et al. (2010) a relative humidity dependence of varying $\gamma$ between $10^{-5}$ and $10^{-3}$ is described, the value is used here is based on Hodzic et al. (2006), who tested $\gamma$ values between $10^{-6}$ and 0.3 , deriving 0.1 as the best $\gamma$ value for minimizing the model error compared to observations. Compared to the other referenced studies, this is an upper limit.

\section{$\begin{array}{ll}3.5 & \mathrm{O}_{3}\end{array}$}

Studies of the heterogeneous reaction of ozone on dust give a wide range for possible reaction probabilities, from $10^{-10}$ to $10^{-4}$ (Reus et al., 2000; Usher et al., 2003; Mogili et al., 2006; George et al., 2015). Reus et al. (2000) gives $10^{-4}$ as an upper limit for this reaction probability, but George et al. (2015) suggests a more conservative upper limit value of $10^{-5}$. Nevertheless, Nicolas et al. (2009) conclude that a reaction probability of $10^{-6}$ is a realistic number in terms of atmospheric environmental conditions, and this value was adopted here.

\section{$\begin{array}{ll}3.6 & \mathrm{HO}_{2}\end{array}$}

$\mathrm{HO}_{2}$ reaction probability is highly variable and strongly depends on transition metal ions contained in the aerosol (Tilgner et al., 2005; Mao et al., 2013; George et al., 2013; Huijnen et al., 2014). Furthermore, this reaction can also take place on cloud droplets. Estimates for $\gamma$ range between 0.02 and 1 (Jacob, 2000; Remorov et al., 2002; Thornton and Abbatt, 2005; Taketani et al., 2008; George et al., 2013; Mao et al., 2013). Whalley et al. (2015) measured $\mathrm{HO}_{2}$ in clouds and found a decrease in $\mathrm{HO}_{2}$ concentrations up to $90 \%$. De-
Table 3. Overview of sensitivity runs.

\begin{tabular}{ll}
\hline Run & Description \\
\hline REF & All heterogeneous reactions \\
noN2O5 & All except $\mathrm{N}_{2} \mathrm{O}_{5}$ reaction \\
noNO3 & All except $\mathrm{NO}_{3}$ reaction \\
noNO2 & All except $\mathrm{NO}_{2}$ reaction \\
noHNO3 & All except $\mathrm{HNO}_{3}$ reaction \\
noHO2 & All except $\mathrm{HO}_{2}$ reaction \\
noO3 & All except $\mathrm{O}_{3}$ reaction \\
\hline
\end{tabular}

pending on the compounds in the particle aqueous phase, heterogeneous reaction of $\mathrm{HO}_{2}$ produces either $\mathrm{H}_{2} \mathrm{O}_{2}$ or $\mathrm{H}_{2} \mathrm{O}$. Consequently, this heterogeneous reaction can be a terminal radical sink or not (Mao et al., 2013; Whalley et al., 2015). Here, we do not account for a terminal sink, but let the heterogeneous reaction of $\mathrm{HO}_{2}$ produce $\mathrm{H}_{2} \mathrm{O}_{2}$ and use the $\gamma$ recommended by Jacob (2000) of 0.2 .

\section{Setup of sensitivity runs}

To test the six heterogeneous reactions (see Table 1), six sensitivity runs were designed and performed with both models. For EMEP MSC-W, a spin-up of 6 months and for ECHAMHAMMOZ one of 12 months is used. Afterwards, the results for the entire year 2012 are evaluated. The reference run (REF) contains all heterogeneous reactions with the parameterizations given in Table 2 . Each sensitivity run is done with five out of six heterogeneous reactions; the names of the runs show which compound does not undergo heterogeneous reaction. For example, in the noN2O5 run, only the $\mathrm{N}_{2} \mathrm{O}_{5}$ heterogeneous reaction is turned off. An overview of the simulations is given in Table 3 .

\section{Results and discussion}

\subsection{Surface area density}

Aerosols consist of a variety of compounds in the gas, liquid, or solid phase, and the shapes of aerosols vary greatly (Pöschl, 2005). Large-scale models cannot explicitly treat the morphology of aerosols. In EMEP MSC-W and ECHAMHAMMOZ, distribution functions and median radii are used to simulate the aerosol population. Based on this approach, surface area density $\left(S_{\mathrm{a}}\right)$ is calculated considering the aerosol distribution, the median radius and assuming spherical particles. This assumption is good for liquid aerosols behaving as small water droplets. For dry particles, this assumption can lead to an underestimation of $S_{\mathrm{a}}$ due to folded or porous structures (Buseck and Posfai, 1999).

In van Donkelaar et al. (2015), satellite retrievals and the Goddard Earth Observing System chemical transport model (GEOS-Chem) are used to derive global surface $\mathrm{PM}_{2.5}$ es- 

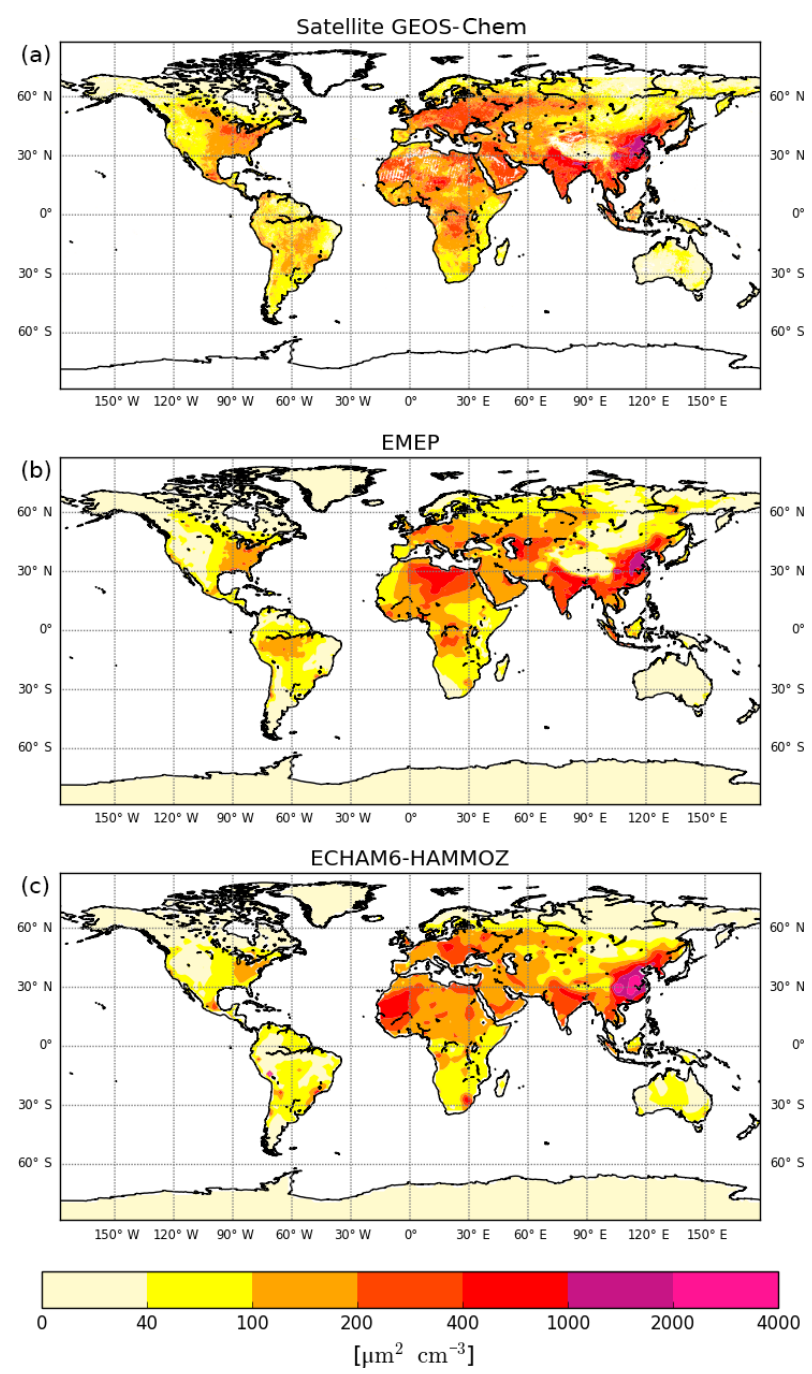

Figure 2. Satellite estimated (a), and simulated surface area densities by EMEP (b) and ECHAM-HAMMOZ (c) at ground level. The satellite data are an average value for the time period 2010-2012 from van Donkelaar et al. (2015). The model data are for 2012 and the lowest model level.

timates with a resolution of $10 \mathrm{~km} \times 10 \mathrm{~km}$ in the time period between 1998 and 2012. The physical relation between aerosol optical depth (AOD) and surface area is described in the Supplement of van Donkelaar et al. (2015).

Figure 2 shows the estimated $\mathrm{PM}_{2.5}$ surface area by van Donkelaar et al. (2015) and the modelled surface area density $\left(S_{\mathrm{a}}\right)$ from EMEP MSC-W and ECHAM-HAMMOZ as the ground-level annual mean for 2012 over land. Although these data sets are not strictly comparable, since the van Donkelaar et al., 2015 estimate in itself relies partly on various assumptions of a third chemical transport model, GEOSChem (van Donkelaar et al., 2015), the general patterns of the models agree well with the surface area density estimation. Both models capture the east-west gradient in $S_{\text {a }}$ over North America even if the total $S_{\text {a }}$ value is comparably lower in both models. Similarly, in the satellite GEOS-Chem product, Europe has slightly higher $S_{\mathrm{a}}$ values than the models produce. In contrast, the $S_{\mathrm{a}}$ values over India are captured very well, and the peak values in east Asia are also produced by both models, while ECHAM-HAMMOZ simulates highest $S_{\mathrm{a}}$ values among the three data sets in east Asia. An overestimation of both models compared to satellite GEOS-Chem happens over north Africa. In South America, EMEP MSC$\mathrm{W}$ performs better than ECHAM-HAMMOZ due to larger contributions from secondary organic aerosol (SOA) formation. EMEP uses a more complex SOA scheme (Bergström et al., 2012; Simpson et al., 2012) which allows for oxidation ("aging") of semivolatile organic vapours. In ECHAMHAMMOZ, an adjusted amount of organic material also covering SOA is emitted, but the amount does not close the gap leading to a lower $S_{\mathrm{a}}$ compared to EMEP MSC-W and satellite GEOS-Chem.

\subsection{Impacts of sensitivity tests}

To evaluate the impact of our heterogeneous reactions, the six sensitivity runs were compared to the reference run containing all heterogeneous reactions. By turning off one heterogeneous reaction in each sensitivity run, the impact of each reaction can be estimated. Tables $4-5$ show the differences in percent between the sensitivity runs and the reference run for EMEP MSC-W and ECHAM-HAMMOZ, as averaged over regions of North America (NA), Europe (EUR), east Asia (EA), and south Asia (SA) (regions defined as in Fiore et al., 2009). Tables S1-S2 in the Supplement give absolute differences in ppb or ppt. The main focus of this evaluation is on the effect of the heterogeneous reactions on ozone mixing ratios. (Also, in order to test the importance of year-to-year variability, the EMEP model was additionally run for the year 2011. The results, given in Table S3, are almost identical to those shown for 2012 in Table 4 and thus not discussed further here.)

For the reference runs, EMEP MSC-W and ECHAMHAMMOZ simulate very similar values for ozone, with ECHAM-HAMMOZ giving somewhat lower mixing ratios. Also $\mathrm{NO}_{x}$ values are similar in Asia but differ by approximately $60-100 \%$ in North America and Europe. In terms of other reactive nitrogen species, EMEP MSC-W has overall higher $\mathrm{NO}_{y}$ levels and especially PAN. This difference in $\mathrm{NO}_{y}$ availability is expected given the impact of EMEP's $\mathrm{NH}_{3}$ emissions in the formation of ammonium nitrate, thus extending the lifetime of reactive nitrogen species, on top of general differences in emissions and chemical mechanisms.

Tables 4-5 clearly show increases in $\mathrm{O}_{3}$ from all the sensitivity runs when the heterogeneous reaction is turned off, except for the sensitivity run without heterogeneous $\mathrm{NO}_{2}$ reaction in east Asia. In this region, the special case of ozone titration (Wild and Akimoto, 2001) leads to an ozone loss due to $\mathrm{NO}_{2}$ instead of production: lowering $\mathrm{NO}_{2}$ in this region of very high $\mathrm{NO}_{x}$ regions means reducing a loss process. Even 
Table 4. Impacts of gas-aerosol reactions on regional ground-level average mixing ratios of $\mathrm{O}_{3}$ and key $\mathrm{NO}_{y}$ compounds: EMEP model, year 2012 .

\begin{tabular}{|c|c|c|c|c|c|c|c|c|c|}
\hline Region & Run & Unit & $\mathrm{O}_{3}$ & $\mathrm{NO}_{x}$ & $\mathrm{NO}_{y}$ & $\mathrm{HNO}_{3}$ & PAN & $\mathrm{N}_{2} \mathrm{O}_{5}$ & $\mathrm{NO}_{3}$ \\
\hline NA & REF & Conc*: & 40.33 & 0.82 & 1.81 & 0.21 & 0.55 & 5.08 & 4.54 \\
\hline NA & noN2O5 & $\%:$ & 5 & 9 & 4 & -10 & 8 & 160 & 59 \\
\hline NA & noHO2 & $\%:$ & 0 & -1 & 0 & 1 & 1 & -2 & -10 \\
\hline NA & noHNO3 & $\%:$ & 0 & 0 & -2 & 18 & 0 & 0 & 0 \\
\hline NA & noNO2 & $\%:$ & 0 & 2 & 1 & -1 & 0 & 4 & 2 \\
\hline NA & noNO3 & $\%:$ & 0 & 0 & 0 & 0 & 0 & 1 & 3 \\
\hline NA & noO3 & $\%:$ & 0 & 0 & 0 & 0 & 0 & 0 & 0 \\
\hline EUR & REF & Conc*: & 40.89 & 1.01 & 2.43 & 0.25 & 0.54 & 7.73 & 6.48 \\
\hline EUR & noN2O5 & $\%:$ & 7 & 16 & 3 & -16 & 10 & 280 & 72 \\
\hline EUR & noHO2 & $\%:$ & 1 & -3 & 0 & 1 & 4 & -4 & -14 \\
\hline EUR & noHNO3 & $\%:$ & 1 & 0 & -6 & 58 & 0 & 0 & 3 \\
\hline EUR & noNO2 & $\%:$ & 0 & 5 & 1 & -1 & -1 & 6 & 4 \\
\hline EUR & noNO3 & $\%:$ & 0 & 0 & 0 & 0 & 0 & 2 & 10 \\
\hline EUR & noO3 & $\%:$ & 0 & 0 & 0 & 0 & 0 & 0 & 2 \\
\hline EA & $\mathrm{REF}$ & Conc*: & 43.96 & 2.23 & 4.63 & 0.54 & 0.89 & 12.59 & 5.52 \\
\hline EA & noN2O5 & $\%:$ & 8 & 14 & 4 & -19 & 13 & 278 & 106 \\
\hline EA & noHO2 & $\%:$ & 2 & -4 & 0 & 2 & 7 & 0 & -7 \\
\hline EA & noHNO3 & $\%:$ & 0 & 0 & -2 & 13 & 0 & 0 & 0 \\
\hline EA & noNO2 & $\%:$ & -1 & 30 & 9 & -11 & -8 & 13 & 4 \\
\hline EA & noNO3 & $\%:$ & 0 & 0 & 0 & 0 & 0 & 1 & 3 \\
\hline EA & noO3 & $\%:$ & 0 & 0 & 0 & 0 & 0 & 0 & 0 \\
\hline SA & $\mathrm{REF}$ & Conc*: & 47.33 & 1.12 & 2.90 & 0.42 & 0.33 & 10.37 & 12.04 \\
\hline SA & noN2O5 & $\%:$ & 6 & 11 & 1 & -4 & 15 & 139 & 63 \\
\hline SA & noHO2 & $\%:$ & 1 & -3 & 0 & 1 & 5 & -5 & -12 \\
\hline SA & noHNO3 & $\%:$ & 1 & 0 & -8 & 61 & 0 & 1 & 4 \\
\hline SA & noNO2 & $\%:$ & 1 & 4 & 1 & 0 & 1 & 10 & 5 \\
\hline SA & noNO3 & $\%:$ & 1 & 0 & 0 & 0 & 1 & 5 & 11 \\
\hline SA & noO3 & $\%:$ & 0 & 0 & 0 & 0 & 0 & 0 & 0 \\
\hline
\end{tabular}

Notes: Base-case concentrations from the surface level of the model are given in ppt for $\mathrm{NO}_{3}$ and $\mathrm{N}_{2} \mathrm{O}_{5}$; otherwise, they are in ppb (Conc* flags this difference in units). Results for the sensitivity tests are given as (test base)/base in percent. The first column refers to the region over which the annual mean is spatially averaged, and the second column refers to the corresponding run. Regions are defined as follows: NA $\left(15-55^{\circ} \mathrm{N} ; 60-125^{\circ} \mathrm{W}\right), \mathrm{EU}\left(25-65^{\circ} \mathrm{N} ; 10^{\circ} \mathrm{W}-50^{\circ} \mathrm{E}\right), \mathrm{EA}$ $\left(15-50^{\circ} \mathrm{N} ; 95-160^{\circ} \mathrm{E}\right)$, and SA $\left(5-35^{\circ} \mathrm{N} ; 50-95^{\circ} \mathrm{E}\right)$.

if the models agree on the direction of the impact of heterogeneous reaction on $\mathrm{O}_{3}$, they do not agree on the strength of the reactions.

For both models, the $\mathrm{N}_{2} \mathrm{O}_{5}$ reactions have generally (ECHAM-HAMMOZ) or always (EMEP) the biggest effect on $\mathrm{O}_{3}$, with changes of approximately 2-3 ppb (5-9\%). Some other heterogeneous reactions (especially $\mathrm{NO}_{2}, \mathrm{HO}_{2}$, and $\mathrm{HNO}_{3}$ ) gain some significance in highly polluted areas where aerosol surface areas are high, but the two models show quite different responses though in their response to these other gas-aerosol reactions. The EMEP model actually shows rather small impacts of all reactions on $\mathrm{O}_{3}$ except $\mathrm{N}_{2} \mathrm{O}_{5}$, except in east and south Asia where some impacts can approach 10-20\% of that of $\mathrm{N}_{2} \mathrm{O}_{5}$. ECHAM-HAMMOZ, on the other hand, shows quite marked responses to especially the $\mathrm{HNO}_{3}$ reactions but also the $\mathrm{HO}_{2}$ reactions.
The strong response of $\mathrm{O}_{3}$ in ECHAM-HAMMOZ to the $\mathrm{HNO}_{3}$ reaction compared to EMEP seems to be the result of a number of factors. The simplest is that EMEP allows this reaction only on coarse aerosol and thus has a smaller surface area for this reaction, especially on dust. Another explanation is that the model sensitivities to $\mathrm{NO}_{x}$ changes may be different, possibly caused by chemical differences or the different horizontal resolutions of the models. Ozone chemistry (and even the switch from production to loss) can be very sensitive to $\mathrm{NO}_{x}$ concentration levels, especially in unpolluted areas (Crutzen et al., 1999; Sillman et al., 1990). $\mathrm{NO}_{x}$ plumes from ships or power plants emitted into large model grid cells might well produce more $\mathrm{O}_{3}$ in one model than the other, leading to different sensitivities to $\mathrm{NO}_{x}$ emissions (von Glasow et al., 2003; Vinken et al., 2011). The EMEP model has in fact a psuedo-species "SHIPNOx" by which $50 \%$ of $\mathrm{NO}_{x}$ from ship plumes are given a pathway 
Table 5. Impacts of gas-aerosol reactions on regional ground-level average mixing ratios of $\mathrm{O}_{3}$ and key $\mathrm{NO}_{y}$ compounds. As Table 4 but for the ECHAM-HAMMOZ model.

\begin{tabular}{lllrrrrrrr}
\hline Region & Run & Unit & $\mathrm{O}_{3}$ & $\mathrm{NO}_{x}$ & $\mathrm{NO}_{y}$ & $\mathrm{HNO}_{3}$ & $\mathrm{PAN}$ & $\mathrm{N}_{2} \mathrm{O}_{5}$ & $\mathrm{NO}_{3}$ \\
\hline NA & REF & Conc* & 38.94 & 1.29 & 1.59 & 0.15 & 0.14 & 14.85 & 2.71 \\
NA & noN2O5 & $\%$ & 6 & 7 & 8 & 8 & 8 & 94 & 56 \\
NA & noHO2 & $\%$ & 0 & -1 & -1 & 2 & 1 & 0 & -3 \\
NA & noHNO3 & $\%$ & 6 & -1 & 11 & 127 & 2 & 6 & 11 \\
NA & noNO2 & $\%$ & 0 & 2 & 2 & -1 & -1 & 3 & 2 \\
NA & noNO3 & $\%$ & 0 & 0 & 0 & 0 & 0 & 0 & 1 \\
NA & noO3 & $\%$ & 0 & 0 & 0 & 0 & 0 & 0 & 0 \\
\hline EUR & REF & Conc* & 39.57 & 2.03 & 2.38 & 0.15 & 0.16 & 21.51 & 4.7 \\
EUR & noN2O5 & $\%$ & 7 & 11 & 13 & 12 & 14 & 177 & 61 \\
EUR & noHO2 & $\%$ & 1 & -2 & -1 & 3 & 6 & -1 & -4 \\
EUR & noHNO3 & $\%$ & 5 & -1 & 14 & 227 & 2 & 6 & 14 \\
EUR & noNO2 & $\%$ & 0 & 6 & 4 & -3 & -5 & 5 & 3 \\
EUR & noNO3 & $\%$ & 0 & 0 & 0 & 0 & 0 & 1 & 3 \\
EUR & noO3 & $\%$ & 0 & 0 & 0 & 0 & 0 & 0 & 0 \\
\hline EA & REF & Conc* & 38.51 & 2.1 & 2.54 & 0.17 & 0.26 & 10.05 & 2.64 \\
EA & noN2O5 & $\%$ & 9 & 11 & 13 & 15 & 15 & 311 & 114 \\
EA & noHO2 & $\%$ & 2 & -5 & -2 & 5 & 13 & 1 & -2 \\
EA & noHNO3 & $\%$ & 5 & -1 & 10 & 148 & 1 & 5 & 9 \\
EA & noNO2 & $\%$ & 0 & 29 & 21 & -8 & -21 & 10 & 5 \\
EA & noNO3 & $\%$ & 0 & 0 & 0 & 0 & 0 & 0 & 2 \\
EA & noO3 & $\%$ & 0 & 0 & 0 & 0 & 0 & 0 & 0 \\
\hline SA & REF & Conc* & 44.26 & 1.29 & 1.53 & 0.1 & 0.12 & 15.5 & 6.15 \\
SA & noN2O5 & $\%$ & 5 & 6 & 8 & 13 & 14 & 96 & 35 \\
SA & noHO2 & $\%$ & 1 & -3 & -2 & 5 & 6 & -1 & -4 \\
SA & noHNO3 & $\%$ & 8 & -1 & 39 & 612 & 4 & 8 & 17 \\
SA & noNO2 & $\%$ & 1 & 4 & 3 & -1 & 0 & 8 & 5 \\
SA & noNO3 & $\%$ & 0 & 0 & 0 & 0 & 0 & 2 & 3 \\
SA & noO3 & $\%$ & 0 & 0 & 0 & 0 & 0 & 0 & 0 \\
\hline & & & & & & & & &
\end{tabular}

to $\mathrm{HNO}_{3}$ production, skipping the intermediate $\mathrm{NO}_{2}$ production associated with overestimating $\mathrm{O}_{3}$ production from $\mathrm{NO}$ in pristine environments (Simpson et al., 2015). A further factor is the lack of nitrate aerosol in ECHAM-HAMMOZ. In the EMEP model, $\mathrm{HNO}_{3}$ can take part in ammonium nitrate aerosol (AN) formation, thus extending the lifetime of $\mathrm{NO}_{y}$. Due to the AN, some $\mathrm{HNO}_{3}$ can be recycled back into the atmosphere stabilizing the $\mathrm{HNO}_{3}$ and $\mathrm{NO}_{3}$ mixing ratios.

Table S2 (and Table 5) shows that for ECHAMHAMMOZ omitting the $\mathrm{HNO}_{3}$ reaction on dust and sea salt aerosol increases $\mathrm{NO}_{x}$ by approximately $10-20 \mathrm{ppt}(1 \%)$, whereas in EMEP the change is tiny $(\leq 1 \mathrm{ppt})$. The impact in ECHAM-HAMMOZ can be found over the whole globe, but especially over the oceans, where $\mathrm{NO}_{x}$ is low but still much higher than $\mathrm{NO}_{z}\left(=\mathrm{NO}_{3}+\mathrm{N}_{2} \mathrm{O}_{5}\right)$. Changes in $\mathrm{NO}_{z}$ with this noHNO3 scenario are far higher in ECHAM-HAMMOZ than in EMEP. Even if heterogeneous $\mathrm{HNO}_{3}$ loss does not hugely impact $\mathrm{NO}_{x}$, a small $\mathrm{NO}_{x}$ increase, even if really small, is ubiquitous and can shift the equilibrium between ozone production and loss towards more production, reaching a higher steady state $\mathrm{O}_{3}$ concentration. Also, this re- action has a significant effect on $\mathrm{NO}_{3}$, reducing it in the northern oceans by about $10 \%$ (not shown). $\mathrm{NO}_{3}$ rapidly photolyses and produces $\mathrm{NO}_{2}$ and atomic oxygen $\mathrm{O}_{3}\left({ }^{3} \mathrm{P}\right)$. $\mathrm{NO}_{2}$ subsequently photolyses and results in $\mathrm{NO}$ and a second $\mathrm{O}_{3}\left({ }^{3} \mathrm{P}\right)$. From these two reactions, two ozone molecules can be formed; therefore, $\mathrm{NO}_{3}$ has a high ozone formation potential. Reducing $\mathrm{HNO}_{3}$, and therefore $\mathrm{NO}_{3}$, drastically by the surface reaction in this highly sensitive region leads to a nonlinear response of the model changing the gross ozone production in ECHAM-HAMMOZ by $350 \mathrm{Tg}$, which is a reduction of $7 \%$. This leads to a global more or less uniformly distributed difference of $1-4 \mathrm{ppbv}$ in ozone mixing ratios.

Analysing all the possible differences in these two different models is beyond of the scope of this study, but it may well be that ECHAM-HAMMOZ overestimates the impact of $\mathrm{HNO}_{3}$ due to missing nitrate aerosol formation and EMEP underestimates the impact due to the use of only coarse sea salt and dust aerosol for the $\mathrm{HNO}_{3}$ and $\mathrm{HO}_{2}$ reactions.

As the $\mathrm{N}_{2} \mathrm{O}_{5}$ reactions have the greatest impact on tracer concentrations among our sensitivity tests, the spatial and temporal differences between the reference run and the sen- 

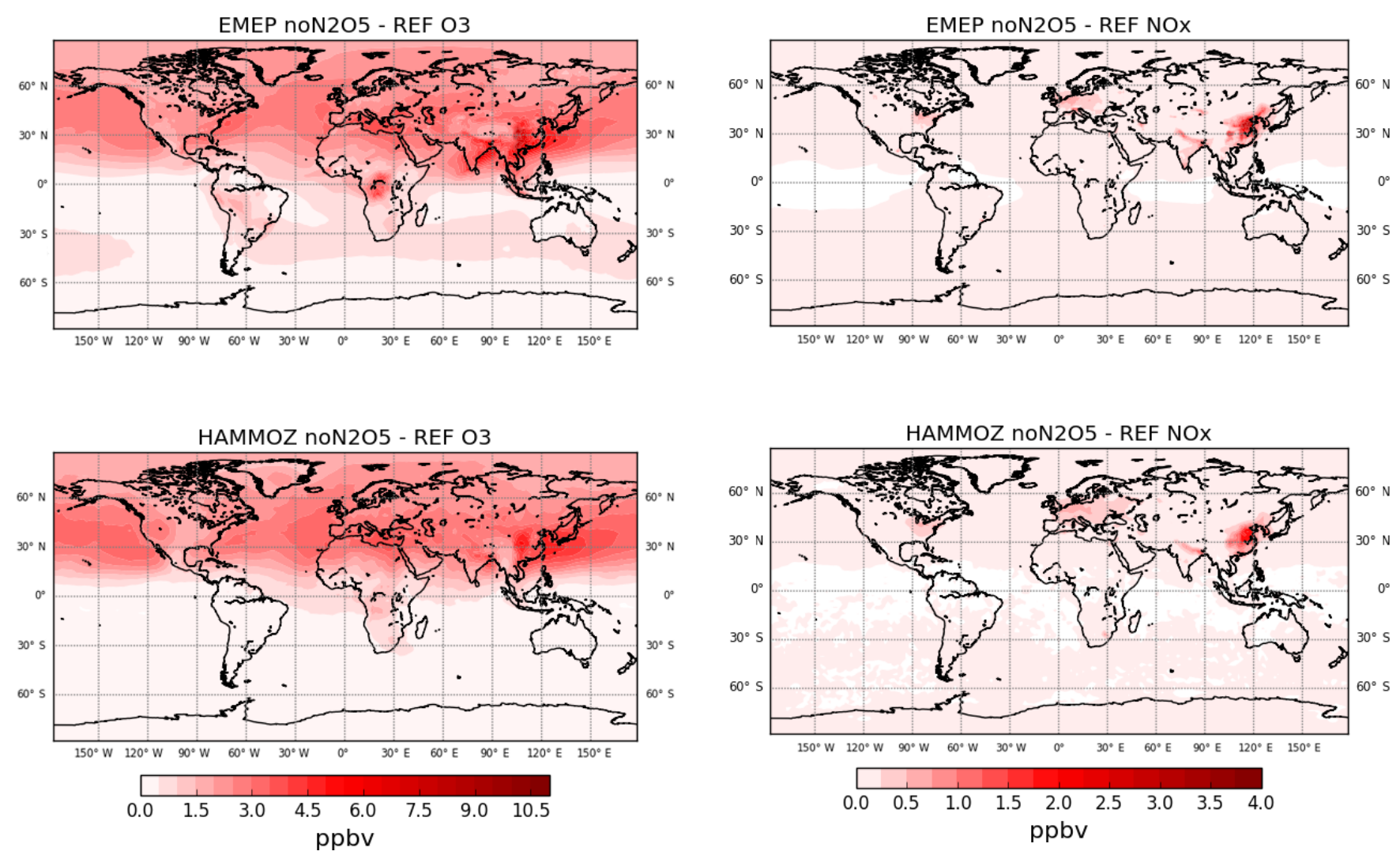

Figure 3. Differences in annual mean ground-level ozone mixing ratio between the reference run (REF) and the sensitivity run (noN2O5) for 2012. Since the reference run was subtracted from the noN2O5 run, positive values show higher values in noN2O5 than in REF.

sitivity run (noN2O5) have been investigated in more detail. Figures 3 and 4 show the difference between the mixing ratios of $\mathrm{O}_{3}$ and $\mathrm{NO}_{x}$ in the reference run and in the sensitivity run without the $\mathrm{N}_{2} \mathrm{O}_{5}$ reactions. Both models show the largest changes in regions where high aerosol loadings and high $\mathrm{NO}_{x}$ emissions can be found, such as the northeast US, Europe, south Asia, and east Asia.

Converting $\mathrm{N}_{2} \mathrm{O}_{5}$ to $\mathrm{HNO}_{3}$ on aerosol surfaces introduces an additional sink for $\mathrm{NO}_{x}$, because $\mathrm{HNO}_{3}$ is rapidly (in EMEP) or immediately (in ECHAM-HAMMOZ) lost via dry and wet deposition, and reactive uptake on aerosols, after it is produced. Therefore, $\mathrm{NO}_{x}$ mixing ratios are lowered in the reference run (REF) compared to the simulation without the heterogeneous reaction noN2O5, as can be seen in Fig. 4.

For ozone, the differences propagate through the whole Northern Hemisphere due to the longer lifetime of $\mathrm{O}_{3}$ compared to $\mathrm{NO}_{x}$ (Fig. 3). Again, both models simulate similar patterns with regard to the spatial distribution of changes due to $\mathrm{N}_{2} \mathrm{O}_{5}$.

Especially for east Asia, the impact of heterogeneous reactions cannot be neglected. High nitrate loadings in ammonium-poor regions verify the importance shown by

Figure 4. As Fig. 3 but for annual mean ground-level $\mathrm{NO}_{x}$ mixing ratios.

other models (Pathak et al., 2009). In the Southern Hemisphere, $\mathrm{N}_{2} \mathrm{O}_{5}$ and the other heterogeneous reactions evaluated in this study have much smaller impacts on ozone and $\mathrm{NO}_{x}$ than seen in the Northern Hemisphere (Figs. 3, 4).

To explore the seasonal impact of $\mathrm{N}_{2} \mathrm{O}_{5}$ reactions, Fig. 5 shows monthly values for tracer mixing ratios and surface area density from both models for the different northern hemispheric regions. In general, the models produce comparable seasonal cycles for the gas tracers and surface area density. Strongest changes in seasonal cycles are found in the noN2O5 run. In the noN2O5 run, $\mathrm{N}_{2} \mathrm{O}_{5}$ builds up during wintertime, because it is thermally unstable and photolabile. Including the heterogeneous uptake leads to a strong $\mathrm{N}_{2} \mathrm{O}_{5}$ reduction in both models, yielding a flatter seasonal curve. The loss of $\mathrm{N}_{2} \mathrm{O}_{5}$ in going from noN2O5 to REF leads to a decrease in $\mathrm{NO}_{2}, \mathrm{NO}_{3}$, and PAN. Here, models slightly differ. EMEP displays a stronger reduction in $\mathrm{NO}_{3}$ and PAN, since it has in both runs higher mixing ratios compared to ECHAM-HAMMOZ. Removing $\mathrm{NO}_{2}$ from the system leads in both models to a reduction of ozone. Although the impact of $\mathrm{N}_{2} \mathrm{O}_{5}$ heterogeneous reaction on $\mathrm{NO}_{2}$ is higher in winter and lowest during summer, the greatest change in $\mathrm{O}_{3}$ can be found during spring. This can be explained by the availability of $\mathrm{N}_{2} \mathrm{O}_{5}$ and ozone production strength. As stated before, $\mathrm{N}_{2} \mathrm{O}_{5}$ is formed during nighttime; therefore, less sunlight is 
(a)

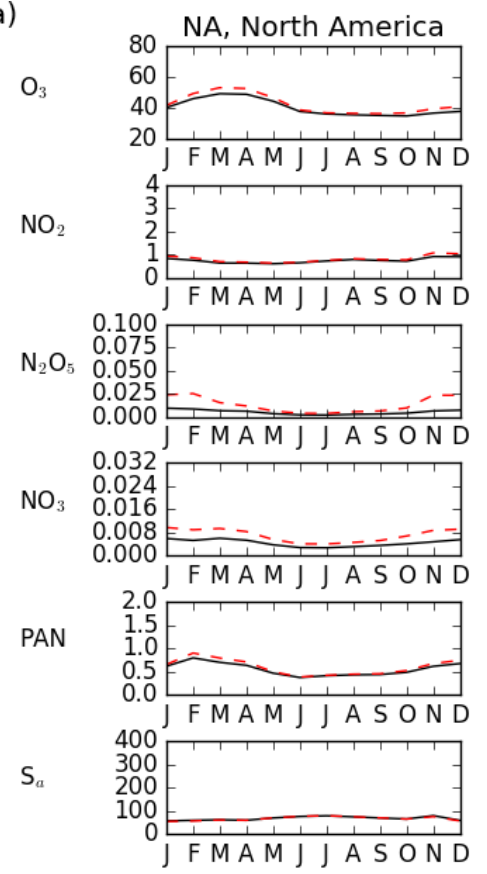

(b)

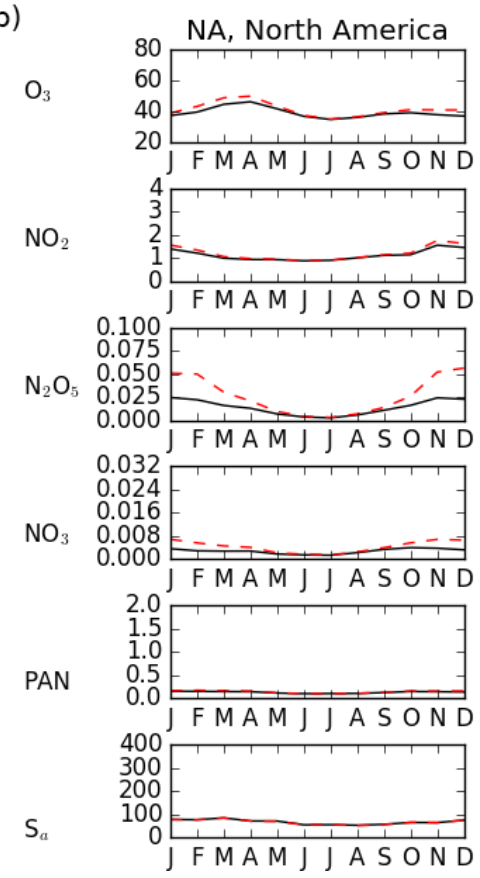

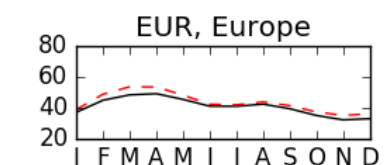
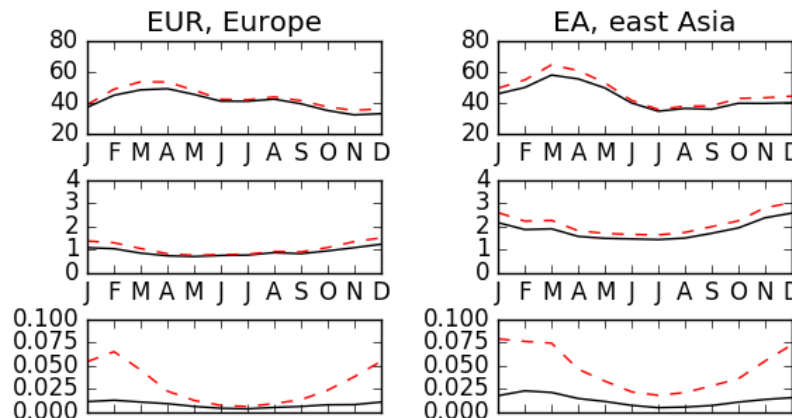

0.000 J F A J J A S O N

0.024

0.016
0.008

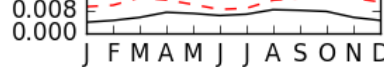
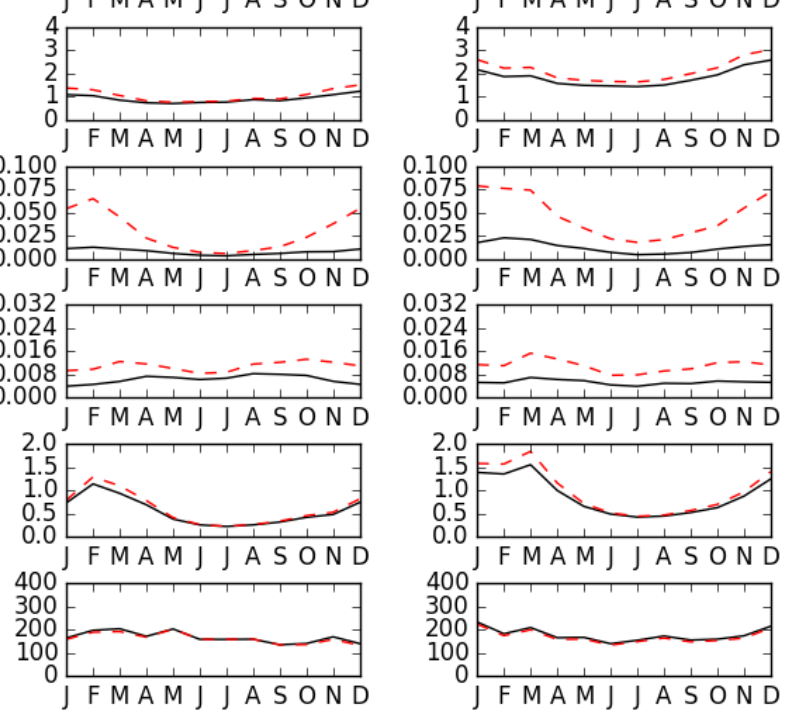

0.000
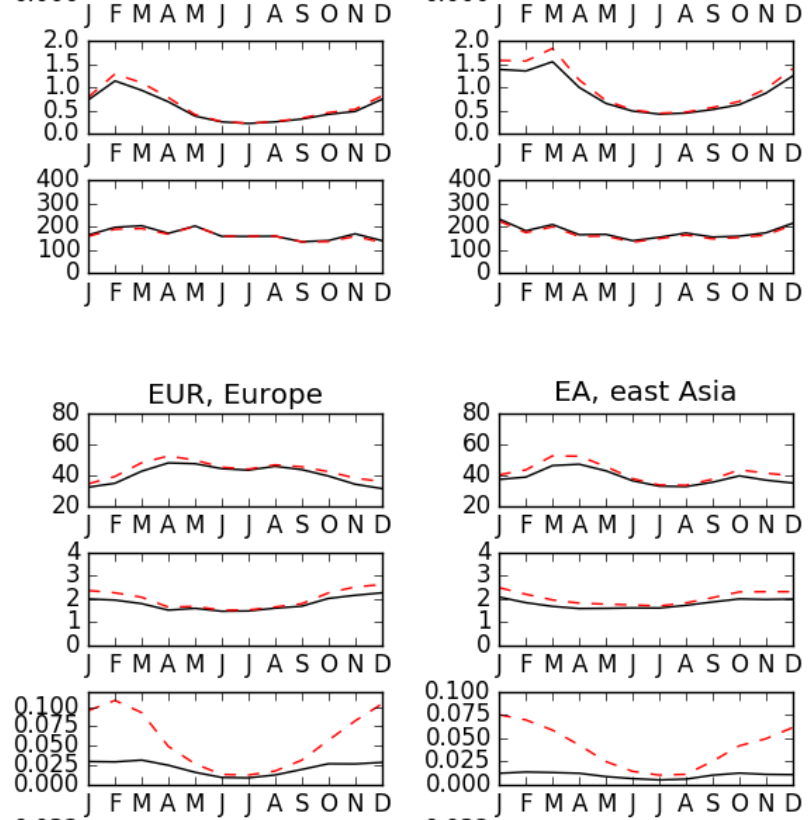

0.032

0.024

0.016
0.008
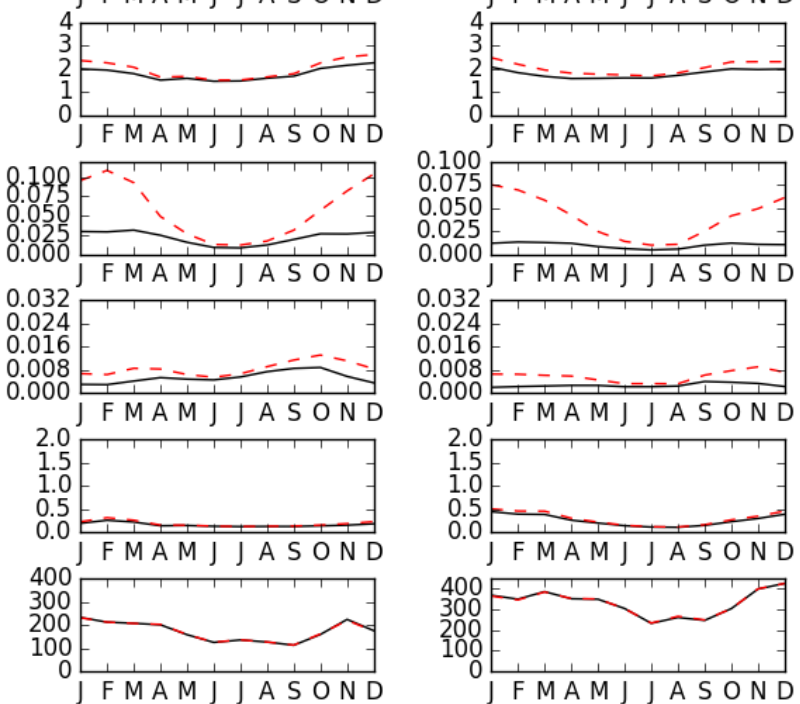
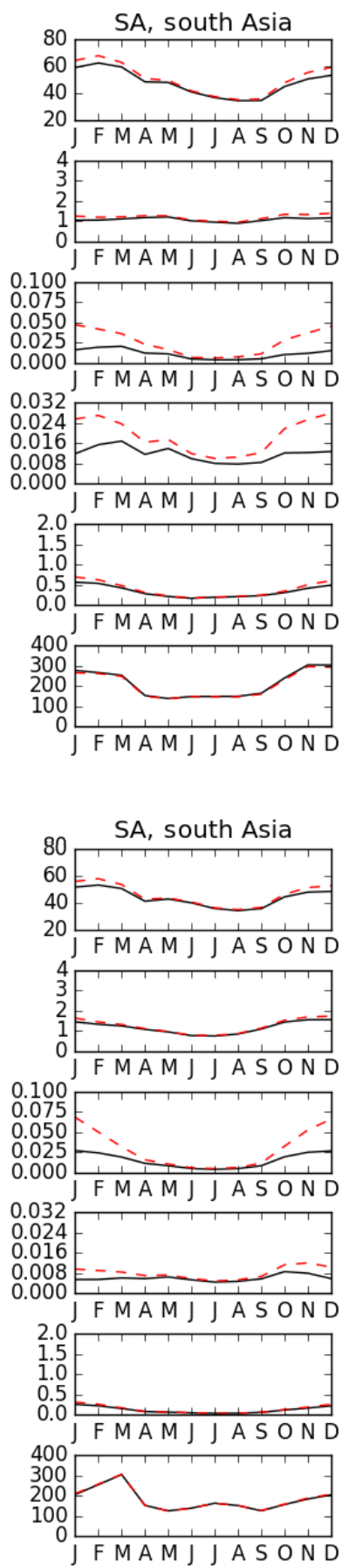

Figure 5. Changes in near-surface $\mathrm{O}_{3}, \mathrm{NO}_{2}, \mathrm{~N}_{2} \mathrm{O}_{5}, \mathrm{NO}_{3}, \mathrm{PAN}$, and $S_{\mathrm{a}}$ for the base case (solid black line) and noN2O5 case (dashed red line) for EMEP (a) and ECHAM-HAMMOZ (b). Plots show monthly gas-phase mixing ratios in ppbv and surface area density in $\mu^{2} \mathrm{~cm}^{-3}$ for different regions as defined above.

favourable. In contrast, to form ozone, light is needed. Still, high $\mathrm{N}_{2} \mathrm{O}_{5}$ concentrations, enough surface area, and a sufficiently high ozone production can be found during spring, leading to the biggest change in $\mathrm{O}_{3}$ production during this season. During winter, nights are longer, leading to inactive photochemistry. Therefore, heterogeneous chemistry is ef- ficient. Nevertheless, a rather inactive photochemistry also leads to less ozone production. Compared to spring, the impact seen here is lower because of the already low ozone formation rate.

An important question is how sensitive the results are to the particular values chosen for the $\gamma$ values. This is a com- 
plicated question, since these reactions also change the composition of $\mathrm{NO}_{y}$ in the atmosphere, the lifetime of $\mathrm{NO}_{2}$, and hence the photooxidation processes leading to $\mathrm{O}_{3}$. In order to address this, additional runs with the EMEP model in four new configurations were performed, including

1. $\gamma=0.01$ for $\mathrm{N}_{2} \mathrm{O}_{5}$, a value lower than typical values, and at the low end of estimates (see Sect. 3.1);

2. $\gamma=0.1$ for $\mathrm{N}_{2} \mathrm{O}_{5}$, equivalent to values used by, e.g. Dentener and Crutzen (1993) and Tie et al. (2001, 2003), which is substantially higher than values obtained for $\gamma_{\mathrm{N}_{2} \mathrm{O}_{5}}$ used here (Table 2, Fig. S1);

3. $\gamma=1.0 \times 10^{-3}$ for $\mathrm{NO}_{2}$, at the top end of estimates (Sect. 3.3); and

4. $\gamma=0.0$ for $\mathrm{NO}_{2}$, since the lowest estimates are extremely low.

The model has been run for new base cases including $\gamma$ as listed above, and for the noN2O5, noHNO3, and (except for test 4 ) noNO2 cases. Results for the regional averages (equivalent to Tables 4-5) are shown in Tables S4 and S5. Considering the $\mathrm{N}_{2} \mathrm{O}_{5}$ tests first, the changes in ozone over, for example, North America range from $3 \%(\gamma=0.01)$ to $8 \%$ $(\gamma=0.1)$, compared to the original estimate in REF of $5 \%$ (Table 4). Changes for $\mathrm{NO}_{x}$ follow a similar pattern (e.g. 6$13 \%$ for NA vs. original $9 \%$ ), but changes for $\mathrm{N}_{2} \mathrm{O}_{5}$ itself are much more significant ( 80 vs. $354 \%$ compared to the original $160 \%$ ).

Considering the $\gamma$ tests for $\mathrm{NO}_{2}$, the test results for the noN2O5 tests generally span those of the original runs, e.g. changes of 4-6\% for ozone in North America vs. $5 \%$ in the original run, or $113-170 \%$ for $\mathrm{N}_{2} \mathrm{O}_{5}$ vs. $160 \%$ for the original case. Test (3), with the high $\gamma=1.0 \times 10^{-3}$ for $\mathrm{NO}_{2}$, does have significant impacts on the $\mathrm{NO}_{x}$ levels though, from, e.g. $2 \%$ in the original run to $16 \%$ in test (3) for NA, or from 30 to $109 \%$ in east Asia. In these runs, the impacts of noNO2 on ozone become comparable to those of noN2O5, and in south Asia the ozone changes from noNO2 actually exceed those from noN2O5.

In test (4), using zero $\gamma$ actually gives results which are very similar to our default $\gamma=1.0 \times 10^{-4}$, suggesting that this reaction only becomes important if higher values than $\times 10^{-4}$ can be justified.

Thus, we find that the exact changes in ozone and $\mathrm{N}$ compounds do depend on the assumed $\gamma$ values, but the relative importance of the different heterogeneous reactions generally remains. The $\mathrm{N}_{2} \mathrm{O}_{5}$ reactions are in nearly all cases the most important driver of ozone changes, but the use of very high values for $\gamma$ for $\mathrm{NO}_{2}$ changes the picture somewhat. We can note though that use of the high 0.1 values for $\gamma\left(\mathrm{NO}_{2}\right)$ leads to quite significant reductions in annual $\mathrm{NO}_{2}$ concentrations, resulting in degraded performance of the EMEP model compared to measurements (not shown), at least across the EMEP observational network in Europe (Tørseth et al., 2012).

\subsection{Comparison with observations}

Surface observations from 20 sites of the Global Atmospheric Watch (GAW; Schultz et al., 2015, 2017a) and Tropospheric Ozone Assessment Report (TOAR) networks, with stations distributed over the world, were used to evaluate ozone concentrations in the reference and $\mathrm{N}_{2} \mathrm{O}_{5}$ sensitivity runs of both models. The GAW data set consists of many sites in North America and Europe but unfortunately few in Asia (e.g. none in China for 2012). Still, sites exist in Japan and these should provide a good indication of ozone formation downwind of mainland China. Mountain sites were excluded from this comparison in order to avoid problems with the interpretation of which model level is most appropriate for comparison. Trinidad Head on the west coast of USA and Mace Head on the west coast of Ireland are also good background stations which capture trends in hemispheric air masses arriving from the Pacific and Atlantic, respectively (Parrish et al., 2009, 2014). To capture the seasonal dependence of $\mathrm{N}_{2} \mathrm{O}_{5}$ uptake on aerosol, daily maximum ozone values were compared with the corresponding interpolated model data. Since the stations were selected to be relatively remote and low-elevation ground stations, the comparison with the coarse grids of the models might be representative.

A total of 6 out of the 20 stations are shown in Figs. 6, 7, and 8 . Both models generally capture the seasonal variation well; fine structures and fluctuations are often reproduced but not equally well by both models and depending on the station. For example, in Tsukuba, Japan, both models simulate the increasing variability during summertime; nevertheless, peak concentrations are still underestimated. EMEP calculates higher peak values than ECHAM-HAMMOZ; in contrast, in Waldhof, Germany, ECHAM-HAMMOZ simulates higher peak values, partially overestimating them compared to the observations.

A closer look at the dashed line compared to the solid line reveals the seasonal highest impact of $\mathrm{N}_{2} \mathrm{O}_{5}$ during springtime. The high impact in the spring pattern can be found in both model simulations.

For example, in Mace Head, Ireland, the springtime ozone formation is clearly decreased by $\mathrm{N}_{2} \mathrm{O}_{5}$ reaction, while during summer the impact is marginal and increases again during winter. Both models start with a spin-up from the reference run; therefore, the winter impact cannot be seen in January. If the models would run for another month, this would show too, indicated by the gap between the reference run and noN2O5 sensitivity run at the very end of the year.

In conclusion, the impact of $\mathrm{N}_{2} \mathrm{O}_{5}$ heterogeneous reactions on chemical ozone production leads to a better agreement of EMEP and ECHAM-HAMMOZ with daily maximum ozone station observations in remote stations. Both models show improvements in model bias, which is expected 

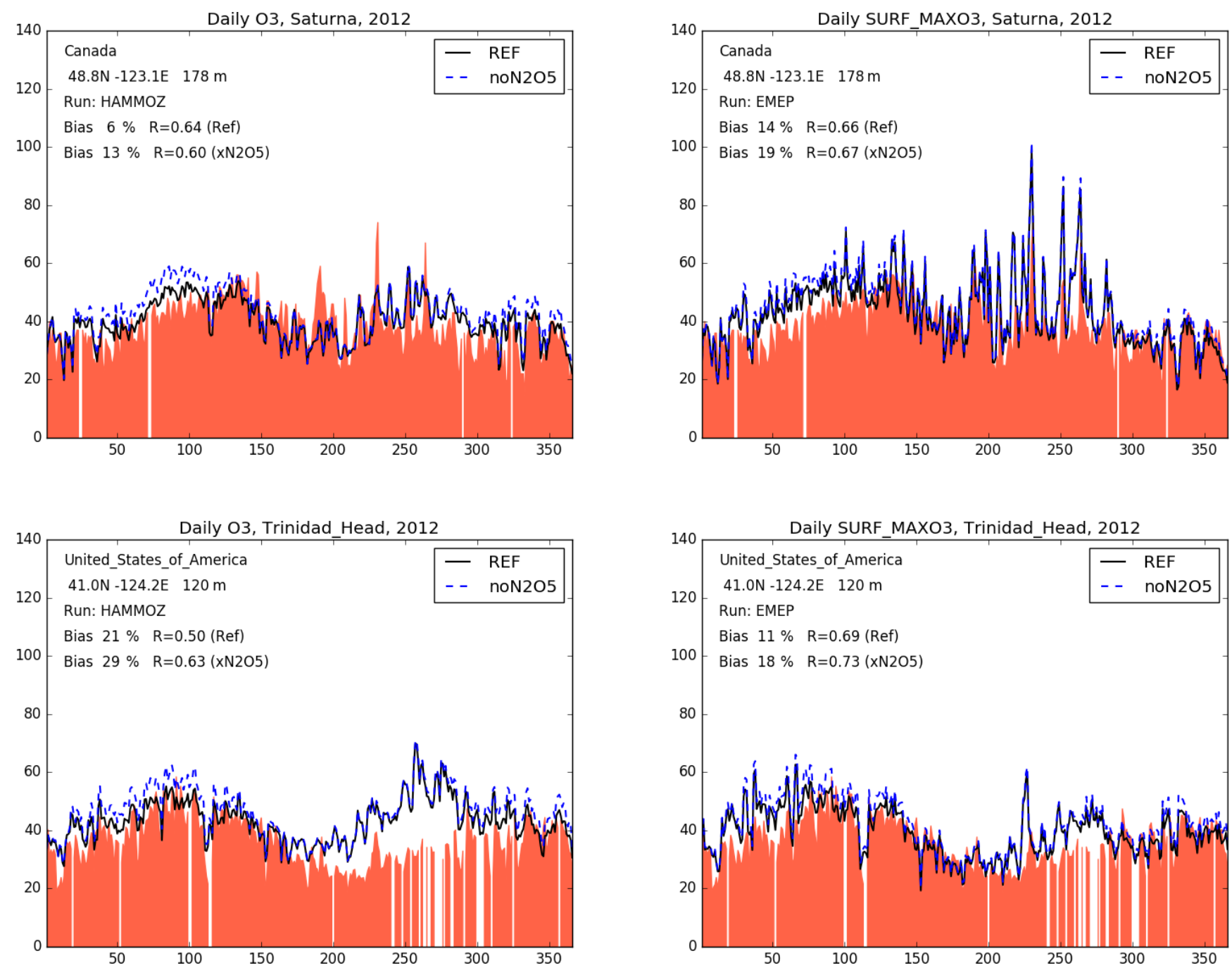

Figure 6. Modelled vs. observed daily maximum ozone (ppbv) for two North American sites (Saturna Island, Canada; Trinidad Head, USA). The shaded area refers to surface station observations, the solid line is the reference run of the model, and the dashed line is the sensitivity run (noN2O5) excluding heterogenous $\mathrm{N}_{2} \mathrm{O}_{5}$ reaction. In the upper left corner, the station location, model, bias, and correlation $R$ are specified.

with prior ozone overestimation and heterogeneous chemistry removes ozone; hence, inclusion of such reactions tends to improve the model performance with regard to bias. Such improvements could also arise when introducing other nitrogen species loss processes to reduce ozone production, having less $\mathrm{NO}_{x}$ emissions, or dynamically inhibiting downward transport of stratospheric ozone. Especially the stratospheric ozone intrusion is assumed to strongly happen during springtime, which would cause the same pattern as we see here in Figs. 6, 7, and 8.

\subsection{Discussion}

The influence of heterogeneous chemistry is known to be important in global chemical transport models, but it is also generally difficult to parameterize for many reasons (Jacob, 2000; Chang et al., 2011; Brown and Stutz, 2012). These include the difficulty of accurately simulating aerosol surface area density available for heterogeneous reactions and the large uncertainty in uptake coefficients. In this section, we briefly compare our results with some previous studies and also comment on some of the remaining difficulties which will need to be tackled in future studies. Concerning modelling, many studies have been published on especially the importance of the $\mathrm{N}_{2} \mathrm{O}_{5}$ reactions (e.g. Dentener and Crutzen, 1993; Tie et al., 2001, 2003; Evans and Jacob, 2005; Alexander et al., 2009; Macintyre and Evans, 2010; Chang et al., 2011).

Table 6 presents a comparison of some reductions in $\mathrm{O}_{3}$ and $\mathrm{NO}_{x}$ due to $\mathrm{N}_{2} \mathrm{O}_{5}$ aerosol uptake. Starting with the annual values, the classic study of Dentener and Crutzen (1993) produced the most dramatic changes in $\mathrm{O}_{3}$ and especially $\mathrm{NO}_{x}$ (40-49\%, depending on assumed $\gamma$ value), with sub- 

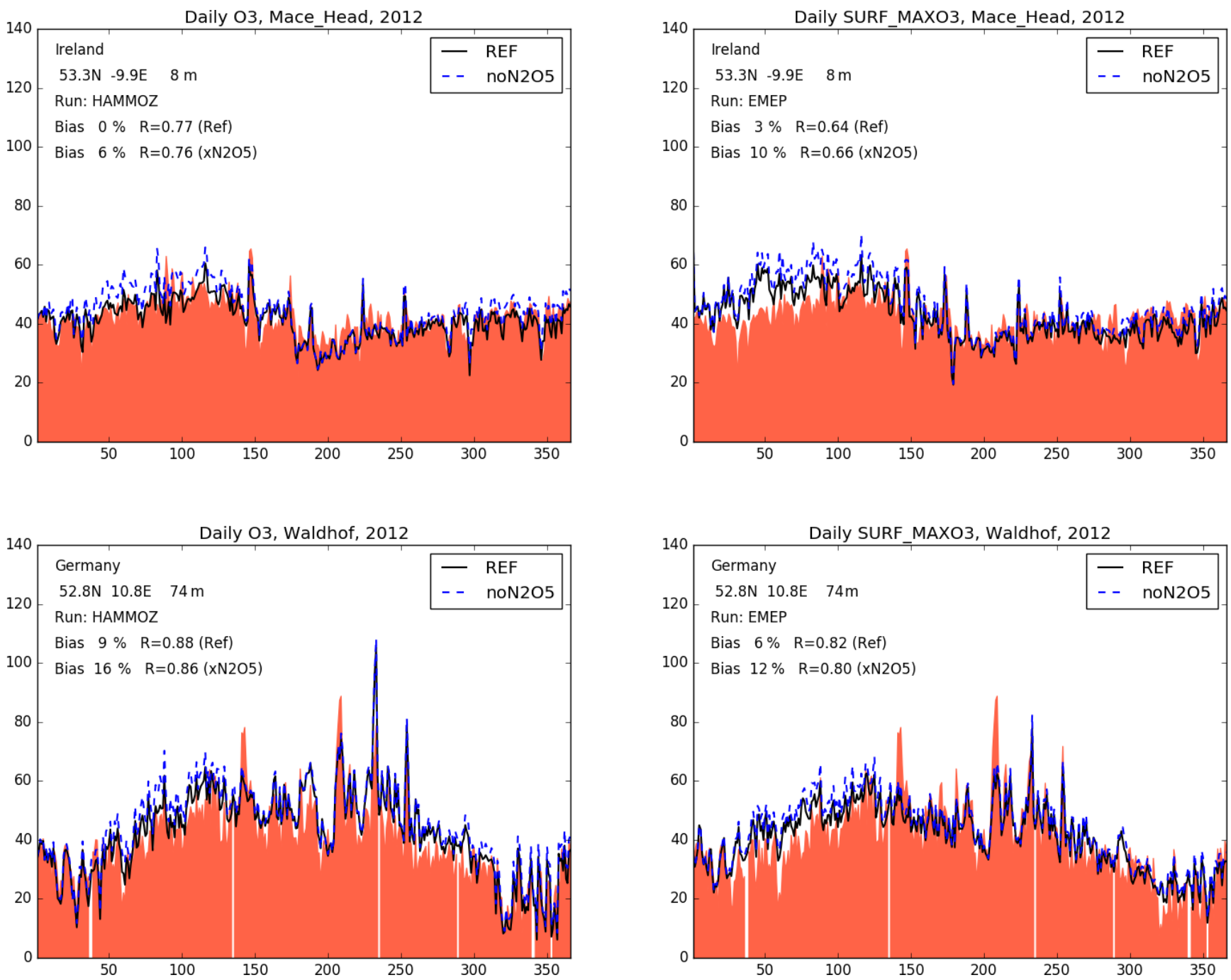

Figure 7. As Fig. 6 but for two European sites, Mace Head (Ireland) and Waldhof (Germany).

sequent studies including ours producing smaller changes. Macintyre and Evans (2010) explored runs with a variety of $\gamma$ coefficients, showing how $\mathrm{O}_{3}$ and $\mathrm{NO}_{x}$ sensitivities change with different values. Our global results do not lie too far from the Macintyre and Evans (2010) results obtained with $\gamma=0.01$.

As seen in Sect. 5.2, the impact of $\mathrm{N}_{2} \mathrm{O}_{5}$ hydrolysis is higher during winter in our study, and Table 6 confirms this for other studies. Dentener and Crutzen (1993) report about a $75 \% \mathrm{NO}_{x}$ and $20 \% \mathrm{O}_{3}$ reduction in their winter period with $\gamma=0.1$. Although Tie et al. (2001) found such dramatic $\mathrm{NO}_{x}$ changes at $45^{\circ} \mathrm{N}$, reductions were much smaller elsewhere (e.g. $3 \%$ at the Equator). A follow-up study of Tie et al. (2003) gave global average $\mathrm{NO}_{x}$ and $\mathrm{O}_{3}$ reductions of 38 and $6 \%$, respectively, significantly lower than that found by Dentener and Crutzen (1993). Our models produce smaller changes again; for example, ECHAM-HAMMOZ simulates a reduction in tropospheric $\mathrm{NO}_{x}$ due to $\mathrm{N}_{2} \mathrm{O}_{5}$ hy- drolysis of $9 \%$ in winter (reductions in surface-level concentrations are greater, at $16 \%$ ). Also, $\mathrm{O}_{3}$ reductions with our models are somewhat lower compared to these other models. EMEP shows the lowest changes in wintertime $\mathrm{NO}_{x}$, though $\mathrm{O}_{3}$ changes are closer to those of ECHAM-HAMMOZ.

Summertime results from Table 6 will not be discussed in detail, but again we see the same trend of more recent models producing smaller changes.

There are many possible reasons for these differences. Firstly, the $\gamma_{\mathrm{N}_{2} \mathrm{O}_{5}}$ values used by Dentener and Crutzen (1993) and Tie et al. $(2001,2003)(=0.1)$ are significantly larger than the typical values of around 0.01-0.04 as calculated in this study (see Fig. S1) and seen in atmospheric observations (Brown et al., 2009; Brown and Stutz, 2012). Macintyre and Evans (2010) tested the model sensitivity to uniform $\gamma_{\mathrm{N}_{2}} \mathrm{O}_{5}$ values and report the highest sensitivity between 0.001 and 0.02 . This is exactly the range of values given frequently by the $\gamma_{\mathrm{N}_{2}} \mathrm{O}_{5}$ parameterization used here. The im- 

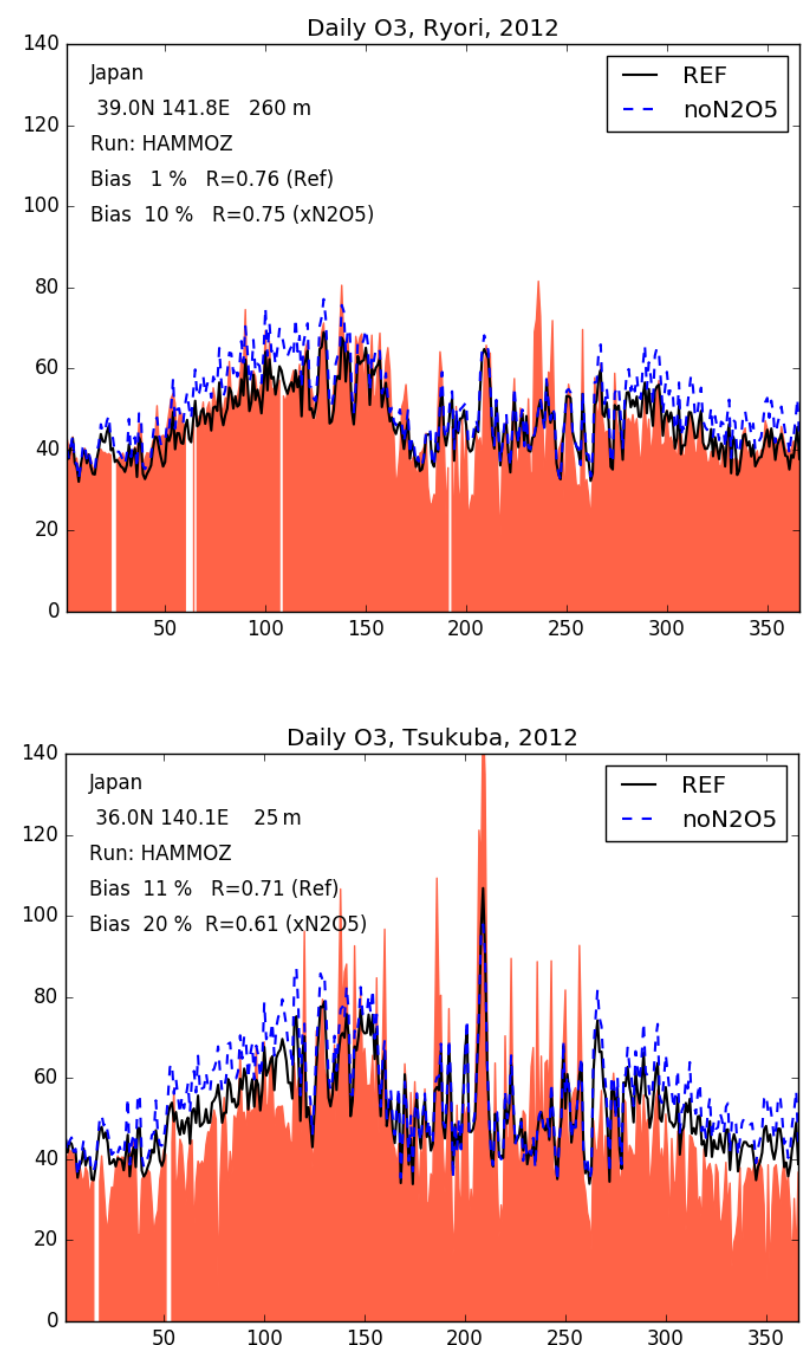

Figure 8. As Fig. 6 but for two Japanese sites, Ryōri and Tsukuba.

pact of the hydrolysis reaction on ozone is indeed stronger with higher $\gamma$, but our main results are relatively insensitive to these necessarily very uncertain choices (Sect. 5.2, Table S4). The ECHAM-HAMMOZ and EMEP models also have a set of other heterogeneous reactions competing with $\mathrm{N}_{2} \mathrm{O}_{5}$ hydrolysis, which again lowers the possible impact of this hydrolysis reaction.

There have been many changes in models, emissions, and indeed the atmosphere since these early studies. For example, the pioneering study of Dentener and Crutzen (1993) had a model with a horizontal resolution of $10 \times 10^{\circ}$, giving grid cells with 100 times the area of the $1 \times 1^{\circ}$ grid used in EMEP or almost 30 times that of ECHAM-HAMMOZ's $1.85 \times 1.85^{\circ}$ grid. This alone will lead to different regimes of ozone productivity. It can also be noted that global chemistry transport models (CTMs) (including changes due to emissions and chemical mechanisms) have improved over the years, so recent models should be expected to have different sensitivities to earlier studies (Wu et al., 2007). Emissions
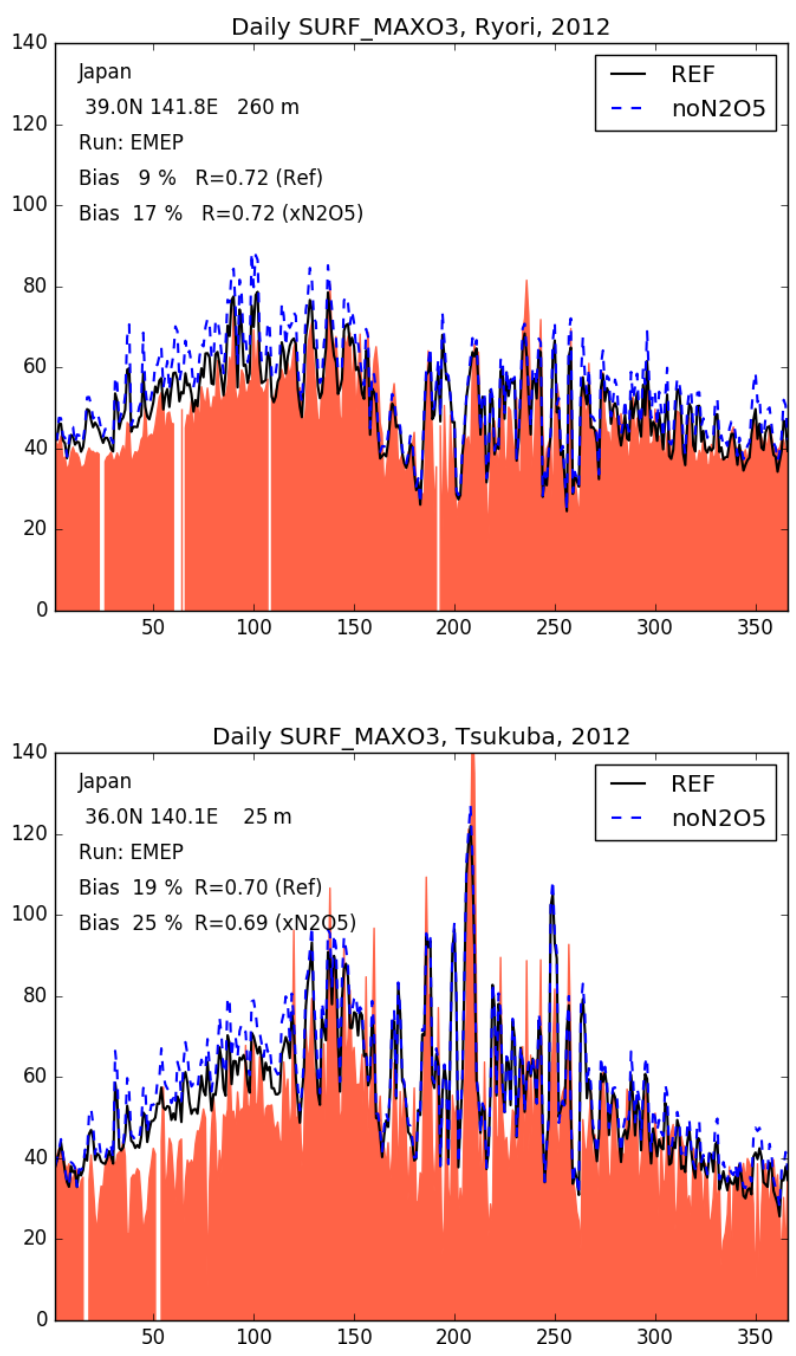

have also changed enormously over this period, especially in Asia (Granier et al., 2011), again with implications for the atmospheric oxidation capacity.

There are many other aspects of heterogeneous chemistry which are potentially important but extremely complex and beyond the scope and abilities of our models. This includes, for example, the strong interactions of $\mathrm{NO}_{2}$ with aerosol water and sulfate formation seen in wintertime haze events in Beijing (Cheng et al., 2016). However, Cheng et al. (2016) were concerned with extreme aerosol pollution events with concentrations exceeding $100 \mu \mathrm{g} \mathrm{m}^{-3}$. These cannot be modelled at present in global-scale models because of the dilution effect of the coarse grid resolution, and such extreme pollution events are likely to only have a local importance. In any case, it is not certain that the mechanism suggested by Cheng et al. (2016) is sufficient to explain some other extreme smog events (e.g. Guo et al., 2017).

Another important aspect for $\mathrm{N}_{2} \mathrm{O}_{5}$ heterogeneous chemistry is the formation of $\mathrm{ClNO}_{2}$. In this case, $\mathrm{N}_{2} \mathrm{O}_{5}$ reacts 
Table 6. Comparison of impacts found by turning off $\mathrm{N}_{2} \mathrm{O}_{5}$ hydrolysis in global model studies. Reductions in $\mathrm{NO}_{x}$ and $\mathrm{O}_{3}$ found in the different global model studies are given in percent.

\begin{tabular}{|c|c|c|c|c|c|}
\hline Model & Domain & $\gamma \mathrm{N}_{2} \mathrm{O}_{5}$ & $\mathrm{NO}_{x}{ }^{\mathrm{a}}$ & $\mathrm{O}_{3}$ & Comments \\
\hline \multicolumn{6}{|l|}{ Annual } \\
\hline Den93 & Trop. & 0.1 & $49^{a}$ & 9 & Globe \\
\hline Den93 & Trop. & 0.01 & $40^{\mathrm{a}}$ & 4 & Globe \\
\hline ME10 & Trop & 0.01 & $\sim 12$ & $\sim 2.5$ & Globe \\
\hline ME10 & Trop & 0.01 & $\sim 30$ & $\sim 6$ & N. extratrop. \\
\hline ME10 & Trop & 0.1 & $\sim 20$ & $\sim 7$ & Globe \\
\hline ME10 & Trop & 0.1 & $\sim 38$ & $\sim 12$ & N. extratrop. \\
\hline HAMMOZ & Trop. & Table 2 & 9.1 & 2.0 & Globe, this study \\
\hline HAMMOZ & Trop. & Table 2 & 15 & 3.1 & $\mathrm{NH}$, this study \\
\hline EMEP & Trop. & Table 2 & 16 & 2.4 & Globe, this study \\
\hline \multicolumn{6}{|l|}{ Winter } \\
\hline Den93 & Trop. & 0.1 & $75^{\mathrm{a}}$ & 20 & NH, Nov-Apr \\
\hline Den93 & Trop. & 0.01 & $66^{\mathrm{a}}$ & 12 & NH, Nov-Apr \\
\hline Tie01 & Trop. & $0.1^{b}$ & 73 & 11 & $45^{\circ} \mathrm{N}, \mathrm{Dec}$ \\
\hline Tie01 & Trop. & $0.1^{b}$ & 3 & 3 & Equator, Dec \\
\hline Tie03 & Trop. & $0.1^{\mathrm{b}}$ & 38 & 6 & Globe, Dec \\
\hline Tie03 & Trop. & $0.1^{\mathrm{b}}$ & 47 & 7 & NH, Dec \\
\hline HAMMOZ & Trop. & Table 2 & 9.1 & 2.0 & Globe, Dec-Feb, this study \\
\hline HAMMOZ & Trop. & Table 2 & 24. & 3.8 & NH, Dec-Feb, this study \\
\hline HAMMOZ & Surface & Table 2 & 16. & 8 & Globe, Dec-Feb, this study \\
\hline EMEP & Surface & Table 2 & 5.1 & 4.9 & Globe, Dec-Feb, this study \\
\hline \multicolumn{6}{|l|}{ Summer } \\
\hline Den93 & Trop. & 0.1 & $45^{\mathrm{a}}$ & 13 & NH, May-Oct \\
\hline Den93 & Trop. & 0.01 & $30^{\mathrm{a}}$ & 5 & NH, May-Oct \\
\hline Tie01 & Trop. & $0.1^{b}$ & 7 & 7 & $45^{\circ} \mathrm{N}$, Jun \\
\hline Tie01 & Trop. & $0.1^{\mathrm{b}}$ & 2 & 2 & Equator, Jun \\
\hline Tie03 & Trop. & $0.1^{b}$ & 6 & 4 & Globe, Dec \\
\hline Tie03 & Trop. & $0.1^{\mathrm{b}}$ & 7 & $\sim 5.5$ & NH, Dec \\
\hline EMEP & Surface & Table 2 & 2.3 & 3.0 & Globe, Jun-Aug, this study \\
\hline HAMMOZ & Surface & Table 2 & 0.4 & 2 & NH, Jun-Aug, this study \\
\hline HAMMOZ & Trop. & Table 2 & 2.4 & 1.3 & NH, Jun-Aug, this study \\
\hline
\end{tabular}

with particulate chlorine to form gas-phase $\mathrm{ClNO}_{2}$, which can photolyse and recycle $\mathrm{NO}_{2}$ (Wang et al., 2016) and alter $\mathrm{NO}_{y}$ composition (Sarwar et al., 2012). Especially in the planetary boundary layer of southern China, high mixing ratios of $\mathrm{ClNO}_{2}$ (> $\left.400 \mathrm{pptv}\right)$ and $\mathrm{N}_{2} \mathrm{O}_{5}(>1 \mathrm{ppbv})$ have been observed (Wang et al., 2016). The formation of $\mathrm{ClNO}_{2}$ lowers the impact of $\mathrm{N}_{2} \mathrm{O}_{5}$ reaction on ozone, because it recycles $\mathrm{NO}_{2}$ and was observed to enhance the ozone peak in southern China up to $16 \%$ (Wang et al., 2016).

Unfortunately, our models (and indeed most global models) lack chlorine chemistry and treatment of chlorine in the aerosol thermodynamics, so they cannot tackle these issues.
Heterogeneous reactions on cloud surfaces, which can be important especially for $\mathrm{HO}_{2}$ uptake depending of the presence of transition metal ions, were also excluded from our study. However, Dentener and Crutzen (1993) included the reaction of $\mathrm{N}_{2} \mathrm{O}_{5}$ on cloud droplets but just found minor changes in $\mathrm{NO}_{x}$ and $\mathrm{O}_{3}$. Jacob (2000) argue that for $\mathrm{O}_{3}$, $\mathrm{HO}_{x}$, and $\mathrm{NO}_{x}$, lifetimes are not significantly reduced in clouds and current knowledge is insufficient to include cloud chemistry in $\mathrm{O}_{3}$ models. In fact, most global model studies exclude the heterogeneous reactions of nitrogen species on clouds. Therefore, further development of CTM cloudchemical systems will be needed before this question can be properly addressed. 
In summary, our study finds a lower but still important impact of $\mathrm{N}_{2} \mathrm{O}_{5}$ hydrolysis on ozone and nitrogen oxides compared to previous model studies. However, earlier studies used rather high $\gamma$ values for $\mathrm{N}_{2} \mathrm{O}_{5}$ and neglected the other heterogeneous reactions. Further, chemical transport models have developed in many ways over the last 20-30 years, and indeed emissions across the globe have dramatically changed over this time period. In this paper, we have illustrated that ECHAM-HAMMOZ and EMEP, two up-to-date model systems, are rather consistent in the importance of $\mathrm{N}_{2} \mathrm{O}_{5}$ reactions, and that such reactions seem to be the most important among the six reactions we tested. Although one can never know if models produce good results for the right reasons, we have shown that both ECHAM-HAMMOZ and EMEP can reproduce even daily ozone variations remarkably well at sites across the globe (one can contrast results for Mace Head between Fig. 7 and the wide range of data from earlier models presented in Wild et al., 2012). We have also demonstrated that both models do a fair job of reproducing surface area density, so we believe our new estimates provide a valuable revision of calculations concerning the impact of heterogeneous reactions in such CTMs.

\section{Conclusions}

Two global transport models were used to investigate the implications of six heterogeneous (gas-aerosol uptake) reactions on ground-level ozone concentrations. Both models were harmonized to use similar parameterizations for most of these reactions, enabling us to compare the impacts of $\mathrm{N}_{2} \mathrm{O}_{5}$, $\mathrm{NO}_{3}, \mathrm{NO}_{2}, \mathrm{O}_{3}, \mathrm{HNO}_{3}$, and $\mathrm{HO}_{2}$ on ozone mixing ratios. Each reaction was evaluated systematically, comparing the reference run to sensitivity simulations, excluding one reaction at a time. Since heterogeneous reactions take place at the aerosol surface area, the modelled surface area density $\left(S_{\mathrm{a}}\right)$ of both models was compared to a satellite product retrieving the surface area. This comparison shows a good agreement in global pattern and especially the capability of both models to capture the extreme aerosol loadings in east Asia.

The analysis of the sensitivity runs confirms that the globally most important heterogeneous reaction is the one of $\mathrm{N}_{2} \mathrm{O}_{5}$. This impact was expected from previous studies, with the surface reactions of $\mathrm{N}_{2} \mathrm{O}_{5}$ having an impact on ozone mixing ratios through removal of reactive $\mathrm{NO}_{x}$ species. This result is loosely consistent with results from earlier studies (e.g. Dentener and Crutzen, 1993; Tie et al., 2001, 2003; Alexander et al., 2009; Macintyre and Evans, 2010), although here the magnitude of changes induced by $\mathrm{N}_{2} \mathrm{O}_{5}$ reaction is at the low end of estimates, which seems to fit a trend, whereby the more recent the study the lower the impacts of these reactions. Some other heterogeneous reactions (especially the ones of $\mathrm{NO}_{2}, \mathrm{HO}_{2}$, and $\mathrm{HNO}_{3}$ ) gain some significance in highly polluted areas where aerosol surface areas are high, but the two models show quite a different response to these other gas-aerosol reactions. The EMEP model actually shows rather small impacts of these reactions, except in east and south Asia where some impacts can approach $10-20 \%$ of that of $\mathrm{N}_{2} \mathrm{O}_{5}$. ECHAM-HAMMOZ, on the other hand, shows quite marked responses to especially the $\mathrm{HNO}_{3}$ reactions. The reasons for this are related to differences in nitrate chemistry and surface area assumptions in the models, and to the differing spatial resolutions. It may well be that ECHAM-HAMMOZ overestimates the impact of $\mathrm{HNO}_{3}$ due to missing nitrate aerosol formation and EMEP underestimates the impact due to the use of only coarse sea salt and dust aerosol for the $\mathrm{HNO}_{3}$ and $\mathrm{HO}_{2}$ reactions.

The reactions of $\mathrm{O}_{3}$ on dust and $\mathrm{NO}_{3}$ on aerosols were found to have only minor effects on ozone in comparison to the other reactions in both models. In terms of global spatial impact, all reactions related to nitrogen species alter atmospheric chemistry downwind of source areas to some extent, with changes being much larger in the polluted Northern Hemisphere than in the Southern Hemisphere.

Evaluation of the models with northern hemispheric ozone surface observations from the GAW/TOAR networks yields a better agreement of the models with observations in terms of daily maximum concentrations, variability, and temporal correlations at most sites when the heterogeneous reactions are incorporated. The impacts of the $\mathrm{N}_{2} \mathrm{O}_{5}$ reactions show strong seasonal variations, with the biggest impacts in springtime when photochemical reactions are active and $\mathrm{N}_{2} \mathrm{O}_{5}$ levels still high.

Due to lack of direct observations, substantial uncertainties remain regarding the impact of heterogeneous reactions on tropospheric reactive gases. It should be noted that neither model had an implementation of the particleliquid-water/nitrate/chloride effects suggested by Bertram and Thornton (2009) and tested by, e.g. Lowe et al. (2015). Further, neither model includes halogen chemistry, which is also known to impact $\mathrm{O}_{3}$ in polluted regions (e.g. Sarwar et al., 2014; Li et al., 2016). The large impact of $\mathrm{N}_{2} \mathrm{O}_{5}$ seen in our work might be somewhat overestimated compared to that we would obtain if the chemistry of $\mathrm{CINO}_{2}$ (which would recycle $\mathrm{NO}_{x}$ ) and other halogens could be included. Such improvements should result in better particle phase chemistry, and will be the subject of future work.

Data availability. We used data from the TOAR database in evaluating the models. The TOAR database and general access to TOAR data are free and unrestricted through the JOIN web interface (https://join.fz-juelich.de/), its associated REST service (see documentation in the Supplement of Schultz et al., 2017a), and the PANGAEA portal (https://doi.org/10.1594/PANGAEA.876108; Schultz et al., 2017a). Data from both models reported here are available at https: //doi.org/10.23728/b2share.45d9c632b8a645309435ea33394b6cce (Simpson and Stadtler, 2018). 


\section{The Supplement related to this article is available online at https://doi.org/10.5194/acp-18-3147-2018-supplement.}

Competing interests. The authors declare that they have no conflict of interest.

Acknowledgements. The authors wish to thank the Jülich Supercomputing Centre (2016) for providing the computing resources for the ECHAM-HAMMOZ simulations. The ECHAM-HAMMOZ model is developed by a consortium composed of ETH Zurich, the Max Planck Institut für Meteorologie, Forschungszentrum Jülich, the University of Oxford, the Finnish Meteorological Institute, and the Leibniz Institute for Tropospheric Research, and managed by the Center for Climate Systems Modeling (C2SM) at ETH Zurich. The EMEP work was funded by the EU FP7 projects ECLAIRE (project number 282910) and EMEP under UNECE, with computer time supported by the Research Council of Norway (Programme for Supercomputing). The project was also supported by the Swedish Climate Modelling Research Project MERGE. GAW surface ozone observation data were retrieved from the World Data Centre for Greenhouse Gases in Tokyo, Japan. We acknowledge the substantial efforts of all data providers for making these measurements.

The article processing charges for this open-access

publication were covered by a Research

Centre of the Helmholtz Association.

Edited by: Kostas Tsigaridis

Reviewed by: two anonymous referees

\section{References}

Aas, W., Tsyro, S., Bieber, E., Bergström, R., Ceburnis, D., Ellermann, T., Fagerli, H., Frölich, M., Gehrig, R., Makkonen, U., Nemitz, E., Otjes, R., Perez, N., Perrino, C., Prévôt, A. S. H., Putaud, J.-P., Simpson, D., Spindler, G., Vana, M., and Yttri, K. E.: Lessons learnt from the first EMEP intensive measurement periods, Atmos. Chem. Phys., 12, 8073-8094, https://doi.org/10.5194/acp-12-8073-2012, 2012.

Ainsworth, E. A., Yendrek, C. R., Sitch, S., Collins, W. J., and Emberson, L. D.: The effects of tropospheric ozone on net primary productivity and implications for climate change, Annu. Rev. Plant Biol., 63, 637-661, https://doi.org/10.1146/annurevarplant-042110-103829, 2012.

Alexander, B., Hastings, M. G., Allman, D. J., Dachs, J., Thornton, J. A., and Kunasek, S. A.: Quantifying atmospheric nitrate formation pathways based on a global model of the oxygen isotopic composition $\left(\Delta^{17} \mathrm{O}\right)$ of atmospheric nitrate, Atmos. Chem. Phys., 9, 5043-5056, https://doi.org/10.5194/acp-9-5043-2009, 2009.

Ammann, M., Cox, R. A., Crowley, J. N., Jenkin, M. E., Mellouki, A., Rossi, M. J., Troe, J., and Wallington, T. J.: Evaluated kinetic and photochemical data for atmospheric chemistry: Volume VI - heterogeneous reactions with liquid substrates, At- mos. Chem. Phys., 13, 8045-8228, https://doi.org/10.5194/acp13-8045-2013, 2013.

Andersson-Sköld, Y. and Simpson, D.: Comparison of the chemical schemes of the EMEP MSC-W and the IVL photochemical trajectory models, Atmos. Environ., 33, 1111-1129, 1999.

Angelbratt, J., Mellqvist, J., Simpson, D., Jonson, J. E., Blumenstock, T., Borsdorff, T., Duchatelet, P., Forster, F., Hase, F., Mahieu, E., De Mazière, M., Notholt, J., Petersen, A. K., Raffalski, U., Servais, C., Sussmann, R., Warneke, T., and Vigouroux, C.: Carbon monoxide $(\mathrm{CO})$ and ethane $\left(\mathrm{C}_{2} \mathrm{H}_{6}\right)$ trends from ground-based solar FTIR measurements at six European stations, comparison and sensitivity analysis with the EMEP model, Atmos. Chem. Phys., 11, 9253-9269, https://doi.org/10.5194/acp11-9253-2011, 2011.

Arens, F., Gutzwiller, L., Baltensperger, U., Gäggeler, H. W., and Ammann, M.: Heterogeneous reaction of $\mathrm{NO}_{2}$ on diesel soot particles, Environ. Sci. Technol., 35, 2191-2199, 2001.

Bauer, S., Balkanski, Y., Schulz, M., Hauglustaine, D., and Dentener, F.: Global modeling of heterogeneous chemistry on mineral aerosol surfaces: influence on tropospheric ozone chemistry and comparison to observations, J. Geophys. Res.-Atmos., 109, D02304, https://doi.org/10.1029/2003JD003868, 2004.

Bergström, R., Denier van der Gon, H. A. C., Prévôt, A. S. H., Yttri, K. E., and Simpson, D.: Modelling of organic aerosols over Europe (2002-2007) using a volatility basis set (VBS) framework: application of different assumptions regarding the formation of secondary organic aerosol, Atmos. Chem. Phys., 12, 8499-8527, https://doi.org/10.5194/acp-12-8499-2012, 2012.

Bertram, T. H. and Thornton, J. A.: Toward a general parameterization of $\mathrm{N}_{2} \mathrm{O}_{5}$ reactivity on aqueous particles: the competing effects of particle liquid water, nitrate and chloride, Atmos. Chem. Phys., 9, 8351-8363, https://doi.org/10.5194/acp-9-8351-2009, 2009.

Bian, H., Chin, M., Hauglustaine, D. A., Schulz, M., Myhre, G., Bauer, S. E., Lund, M. T., Karydis, V. A., Kucsera, T. L., Pan, X., Pozzer, A., Skeie, R. B., Steenrod, S. D., Sudo, K., Tsigaridis, K., Tsimpidi, A. P., and Tsyro, S. G.: Investigation of global particulate nitrate from the AeroCom phase III experiment, Atmos. Chem. Phys., 17, 12911-12940, https://doi.org/10.5194/acp-1712911-2017, 2017.

Binkowski, F. and Shankar, U.: The regional particulate matter model, 1. Model description and preliminary results, J. Geophys. Res., 100, 26191-26209, 1995.

Brown, S. S. and Stutz, J.: Nighttime radical observations and chemistry, Chem. Soc. Rev., 41, 6405-6447, https://doi.org/10.1039/C2CS35181A, 2012.

Brown, S. S., Dube, W. P., Fuchs, H., Ryerson, T. B., Wollny, A. G., Brock, C. A., Bahreini, R., Middlebrook, A. M., Neuman, J. A., Atlas, E., Roberts, J. M., Osthoff, H. D., Trainer, M., Fehsenfeld, F. C., and Ravishankara, A. R.: Reactive uptake coefficients for $\mathrm{N}_{2} \mathrm{O}_{5}$ determined from aircraft measurements during the Second Texas Air Quality Study: comparison to current model parameterizations, J. Geophys. Res., 114, D00F10, https://doi.org/10.1029/2008JD011679, 2009.

Buseck, P. R. and Posfai, M.: Airborne minerals and related aerosol particles: effects on climate and the environment, P. Natl. Acad. Sci. USA, 96, 3372-3379, 1999.

Chang, W. L., Bhave, P. V., Brown, S. S., Riemer, N., Stutz, J., and Dabdub, D.: Heterogeneous atmospheric chemistry, ambi- 
ent measurements, and model calculations of $\mathrm{N}_{2} \mathrm{O}_{5}$ : a review, Aerosol Sci. Tech., 45, 665-695, 2011.

Cheng, Y., Zheng, G., Wei, C., Mu, Q., Zheng, B., Wang, Z., Gao, M., Zhang, Q., He, K., Carmichael, G., Pöschl, U., and $\mathrm{Su}, \mathrm{H} .:$ Reactive nitrogen chemistry in aerosol water as a source of sulfate during haze events in China, Science Advances, 2, e1601530, https://doi.org/10.1126/sciadv.1601530, 2016.

Crutzen, P., Lawrence, M., and Pöschl, U.: On the background photochemistry of tropospheric ozone, International Symposium to Commemorate the 100th Anniversary of the Birth of Carl Gustaf Rossby (Rossby-100), Stockholm, Sweden, 8-12 June 1998, Tellus, 51, 123-146, 1999.

Davies, J. A. and Cox, R. A.: Kinetics of the heterogeneous reaction of $\mathrm{HNO}_{3}$ with $\mathrm{NaCl}$ : effect of water vapor, J. Phys. Chem. A, 102, 7631-7642, 1998.

Davis, J. M., Bhave, P. V., and Foley, K. M.: Parameterization of $\mathrm{N}_{2} \mathrm{O}_{5}$ reaction probabilities on the surface of particles containing ammonium, sulfate, and nitrate, Atmos. Chem. Phys., 8, 52955311, https://doi.org/10.5194/acp-8-5295-2008, 2008.

Dentener, F. J. and Crutzen, P. J.: Reaction of $\mathrm{N}_{2} \mathrm{O}_{5}$ on tropospheric aerosols: impact on the global distributions of $\mathrm{NO}_{x}, \mathrm{O}_{3}$, and $\mathrm{OH}$, J. Geophys. Res.-Atmos., 98, 7149-7163, 1993.

Emmons, L. K., Walters, S., Hess, P. G., Lamarque, J.-F., Pfister, G. G., Fillmore, D., Granier, C., Guenther, A., Kinnison, D., Laepple, T., Orlando, J., Tie, X., Tyndall, G., Wiedinmyer, C., Baughcum, S. L., and Kloster, S.: Description and evaluation of the Model for Ozone and Related chemical Tracers, version 4 (MOZART-4), Geosci. Model Dev., 3, 43-67, https://doi.org/10.5194/gmd-3-43-2010, 2010.

Evans, M. and Jacob, D. J.: Impact of new laboratory studies of $\mathrm{N}_{2} \mathrm{O}_{5}$ hydrolysis on global model budgets of tropospheric nitrogen oxides, ozone, and $\mathrm{OH}$, Geophys. Res. Lett., 32, https://doi.org/10.1029/2005GL022469, 2005.

Fagerli, H. and Aas, W.: Trends of nitrogen in air and precipitation: Model results and observations at EMEP sites in Europe, 19802003, Environ. Pollut., 154, 448-461, 2008.

Fairlie, T. D., Jacob, D. J., Dibb, J. E., Alexander, B., Avery, M. A., van Donkelaar, A., and Zhang, L.: Impact of mineral dust on nitrate, sulfate, and ozone in transpacific Asian pollution plumes, Atmos. Chem. Phys., 10, 3999-4012, https://doi.org/10.5194/acp-10-3999-2010, 2010.

Fiore, A., Dentener, F., Wild, O., Cuvelier, C., Schultz, M., Hess, P., Textor, C., Schulz, M., Doherty, R., Horowitz, L. W., MacKenzie, I. A., Sanderson, M. G., Shindell, D. T., Stevenson, D. S., Szopa, S., Van Dingenen, R., Zeng, G., Atherton, C., Bergmann, D., Bey, I., Carmichael, G., Collins, W. J., Duncan, B. N., Faluvegi, G., Folberth, G., Gauss, M., Gong, S., Hauglustaine, D., Holloway, T., Isaksen, I. S. A., Jacob, D. J., Jonson, J. E., Kaminski, J. W., Keating, T. J., Lupu, A., Marmer, E., Montanaro, V., Park, R. J., Pitari, G., Pringle, K. J., Pyle, J. A., Schroder, S., Vivanco, M. G., Wind, P., Wojcik, G., Wu, S., and Zuber, A.: Multimodel estimates of intercontinental source-receptor relationships for ozone pollution, J. Geophys. Res.-Atmos., 114, https://doi.org/10.1029/2008JD010816, 2009.

Frenzel, A., Scheer, V., Sikorski, R., George, C., Behnke, W., and Zetzsch, C.: Heterogeneous Interconversion Reactions of $\mathrm{BrNO}_{2}, \mathrm{ClNO}_{2}, \mathrm{Br}_{2}$, and $\mathrm{Cl}_{2}$, J. Phys. Chem. A, 102, 13291337, https://doi.org/10.1021/jp973044b, 1998.
Gauss, M., Benedictow, A., and Hjellbrekke, A.-G.: Photo-oxidants: validation and combined maps, Supplementary material to emep status report 1/2011, available at: www.emep.int (last access: 14 February 2018), The Norwegian Meteorological Institute, Oslo, Norway, 2011.

George, C., Ammann, M., D’Anna, B., Donaldson, D., and Nizkorodov, S. A.: Heterogeneous photochemistry in the atmosphere, Chem. Rev., 115, 4218-4258, 2015.

George, I., Matthews, P., Whalley, L., Brooks, B., Goddard, A., Baeza-Romero, M., and Heard, D.: Measurements of uptake coefficients for heterogeneous loss of $\mathrm{HO}_{2}$ onto submicron inorganic salt aerosols, Phys. Chem. Chem. Phys., 15, 12829-12845, 2013.

Gerber, H. E.: Relative-Humidity Parameterization of the Navy Aerosol Model (NAM), NRL Report 8956, Naval Research Laboratory, Washington, DC, 1985.

Goodman, A., Underwood, G., and Grassian, V.: Heterogeneous reaction of $\mathrm{NO}_{2}$ : characterization of gas-phase and adsorbed products from the reaction, $2 \mathrm{NO}_{2}(\mathrm{~g})+\mathrm{H}_{2} \mathrm{O}(\mathrm{a}) \rightarrow \mathrm{HONO}(\mathrm{g})+$ $\mathrm{HNO}_{3}$ (a) on hydrated silica particles, J. Phys. Chem. A, 103, 7217-7223, 1999.

Granier, C., Bessagnet, B., Bond, T., D’Angiola, A., van der Gon, H. D., Frost, G. J., Heil, A., Kaiser, J. W., Kinne, S., Klimont, Z., Kloster, S., Lamarque, J.-F., Liousse, C., Masui, T., Meleux, F., Mieville, A., Ohara, T., Raut, J.-C., Riahi, K., Schultz, M. G., Smith, S. J., Thompson, A., van Aardenne, J., van der Werf, G. R., and van Vuuren, D. P.: Evolution of anthropogenic and biomass burning emissions of air pollutants at global and regional scales during the 1980-2010 period, Climatic Change, 109, 163-190, https://doi.org/10.1007/s10584011-0154-1, 2011.

Grewe, V., Brunner, D., Dameris, M., Grenfell, J., Hein, R., Shindell, D., and Staehelin, J.: Origin and variability of upper tropospheric nitrogen oxides and ozone at northern mid-latitudes, Atmos. Environ., 35, 3421-3433, 2001.

Griffiths, P. T., Badger, C. L., Cox, R. A., Folkers, M., Henk, H. H., and Mentel, T. F.: Reactive uptake of $\mathrm{N}_{2} \mathrm{O}_{5}$ by aerosols containing dicarboxylic acids. Effect of particle phase, composition, and nitrate content, J. Phys. Chem. A, 113, 5082-5090, 2009.

Gross, S. and Bertram, A. K.: Reactive uptake of $\mathrm{NO}_{3}, \mathrm{~N}_{2} \mathrm{O}_{5}, \mathrm{NO}_{2}$, $\mathrm{HNO}_{3}$, and $\mathrm{O}_{3}$ on three types of polycyclic aromatic hydrocarbon surfaces, J. Phys. Chem. A, 112, 3104-3113, 2008.

Gross, S. and Bertram, A. K.: Products and kinetics of the reactions of an alkane monolayer and a terminal alkene monolayer with $\mathrm{NO}_{3}$ radicals, J. Geophys. Res.-Atmos., 114, 7792-7803, https://doi.org/10.1039/B904741G, 2009.

Gross, S., Iannone, R., Xiao, S., and Bertram, A. K.: Reactive uptake studies of $\mathrm{NO}_{3}$ and $\mathrm{N}_{2} \mathrm{O}_{5}$ on alkenoic acid, alkanoate, and polyalcohol substrates to probe nighttime aerosol chemistry, Phys. Chem. Chem. Phys., 11, 7792-7803, 2009.

Guenther, A., Karl, T., Harley, P., Wiedinmyer, C., Palmer, P. I., and Geron, C.: Estimates of global terrestrial isoprene emissions using MEGAN (Model of Emissions of Gases and Aerosols from Nature), Atmos. Chem. Phys., 6, 3181-3210, https://doi.org/10.5194/acp-6-3181-2006, 2006.

Guo, H., Weber, R. J., and Nenes, A.: High levels of ammonia do not raise fine particle $\mathrm{pH}$ sufficiently to yield nitrogen oxide-dominated sulfate production, Sci. Rep.-UK, 7, 12109, https://doi.org/10.1038/s41598-017-11704-0, 2017. 
Hallquist, M., Wenger, J. C., Baltensperger, U., Rudich, Y., Simpson, D., Claeys, M., Dommen, J., Donahue, N. M., George, C., Goldstein, A. H., Hamilton, J. F., Herrmann, H., Hoffmann, T., Iinuma, Y., Jang, M., Jenkin, M. E., Jimenez, J. L., Kiendler-Scharr, A., Maenhaut, W., McFiggans, G., Mentel, Th. F., Monod, A., Prévôt, A. S. H., Seinfeld, J. H., Surratt, J. D., Szmigielski, R., and Wildt, J.: The formation, properties and impact of secondary organic aerosol: current and emerging issues, Atmos. Chem. Phys., 9, 5155-5236, https://doi.org/10.5194/acp9-5155-2009, 2009.

Hanisch, F. and Crowley, J. N.: The heterogeneous reactivity of gaseous nitric acid on authentic mineral dust samples, and on individual mineral and clay mineral components, Phys. Chem. Chem. Phys., 3, 2474-2482, 2001.

Harrison, R. M. and Collins, G. M.: Measurements of reaction coefficients of $\mathrm{NO}_{2}$ and $\mathrm{HONO}$ on aerosol particles, J. Atmos. Chem., 30, 397-406, 1998.

Harrison, R. M. and Yin, J.: Particulate matter in the atmosphere: which particle properties are important for its effects on health?, Sci. Total Environ., 249, 85-101, 2000.

Hauglustaine, D. A., Balkanski, Y., and Schulz, M.: A global model simulation of present and future nitrate aerosols and their direct radiative forcing of climate, Atmos. Chem. Phys., 14, 1103111063, https://doi.org/10.5194/acp-14-11031-2014, 2014.

Henrot, A.-J., Stanelle, T., Schröder, S., Siegenthaler, C., Taraborrelli, D., and Schultz, M. G.: Implementation of the MEGAN (v2.1) biogenic emission model in the ECHAM6-HAMMOZ chemistry climate model, Geosci. Model Dev., 10, 903-926, https://doi.org/10.5194/gmd-10-903-2017, 2017.

Hodzic, A., Bessagnet, B., and Vautard, R.: A model evaluation of coarse-mode nitrate heterogeneous formation on dust particles, Atmos. Environ., 40, 4158-4171, 2006.

Huijnen, V., Williams, J. E., and Flemming, J.: Modeling global impacts of heterogeneous loss of $\mathrm{HO}_{2}$ on cloud droplets, ice particles and aerosols, Atmos. Chem. Phys. Discuss., https://doi.org/10.5194/acpd-14-8575-2014, 2014.

IPCC: Annex I: Atlas of global and regional climate projections, in: Climate Change 2013: The Physical Science Basis. Contribution of Working Group I to the Fifth Assessment Report of the Intergovernmental Panel on Climate Change, edited by: Stocker, T., Qin, D., Plattner, G.-K., Tignor, M., Allen, S., Boschung, J., Nauels, A., Xia, Y., Bex, V., and Midgley, P., book section AI, Cambridge University Press, Cambridge, United Kingdom and New York, NY, USA, 1311-1394, https://doi.org/10.1017/CBO9781107415324.029, 2013.

Jacob, D. J.: Heterogeneous chemistry and tropospheric ozone, Atmos. Environ., 34, 2131-2159, 2000.

Jonson, J. E., Stohl, A., Fiore, A. M., Hess, P., Szopa, S., Wild, O., Zeng, G., Dentener, F. J., Lupu, A., Schultz, M. G., Duncan, B. N., Sudo, K., Wind, P., Schulz, M., Marmer, E., Cuvelier, C., Keating, T., Zuber, A., Valdebenito, A., Dorokhov, V., De Backer, H., Davies, J., Chen, G. H., Johnson, B., Tarasick, D. W., Stübi, R., Newchurch, M. J., von der Gathen, P., Steinbrecht, W., and Claude, H.: A multi-model analysis of vertical ozone profiles, Atmos. Chem. Phys., 10, 5759-5783, https://doi.org/10.5194/acp10-5759-2010, 2010.

Jonson, J. E., Semeena, V. S., and Simpson, D.: Global ozone bias, in: Transboundary particulate matter, photo-oxidants, acidifying and eutrophying components. Status Report 1/2015, 115-128, The Norwegian Meteorological Institute, Oslo, Norway, 2015.

Jülich Supercomputing Centre: JURECA: General-purpose supercomputer at Jülich Supercomputing Centre, Journal of largescale research facilities, 2, https://doi.org/10.17815/jlsrf-2-121, 2016.

Kinnison, D., Brasseur, G., Walters, S., Garcia, R., Marsh, D., Sassi, F., Harvey, V., Randall, C., Emmons, L., Lamarque, J. F., Hess, P., Orlando, J. J., Tie, X. X., Randel, W., Pan, L. L., Gettelman, A., Granier, C., Diehl, T., Niemeier, U., and Simmons, A. J.: Sensitivity of chemical tracers to meteorological parameters in the MOZART-3 chemical transport model, J. Geophys. Res.Atmos., 112, D20302, https://doi.org/10.1029/2006JD007879, 2007.

Kleffmann, J., Becker, K., and Wiesen, P.: Heterogeneous $\mathrm{NO}_{2}$ conversion processes on acid surfaces: possible atmospheric implications, Atmos. Environ., 32, 2721-2729, 1998.

Lamarque, J.-F., Emmons, L. K., Hess, P. G., Kinnison, D. E., Tilmes, S., Vitt, F., Heald, C. L., Holland, E. A., Lauritzen, P. H., Neu, J., Orlando, J. J., Rasch, P. J., and Tyndall, G. K.: CAM-chem: description and evaluation of interactive atmospheric chemistry in the Community Earth System Model, Geosci. Model Dev., 5, 369-411, https://doi.org/10.5194/gmd-5369-2012, 2012.

Li, Q., Zhang, L., Wang, T., Tham, Y. J., Ahmadov, R., Xue, L., Zhang, Q., and Zheng, J.: Impacts of heterogeneous uptake of dinitrogen pentoxide and chlorine activation on ozone and reactive nitrogen partitioning: improvement and application of the WRF-Chem model in southern China, Atmos. Chem. Phys., 16, 14875-14890, https://doi.org/10.5194/acp-16-148752016, 2016.

Liao, H. and Seinfeld, J. H.: Global impacts of gas-phase chemistryaerosol interactions on direct radiative forcing by anthropogenic aerosols and ozone, J. Geophys. Res.-Atmos., 110, https://doi.org/10.1029/2005JD005907, 2005.

Liu, Y., Gibson, E. R., Cain, J. P., Wang, H., Grassian, V. H., and Laskin, A.: Kinetics of heterogeneous reaction of $\mathrm{CaCO}_{3}$ particles with gaseous $\mathrm{HNO}_{3}$ over a wide range of humidity, J. Phys. Chem. A, 112, 1561-1571, 2008.

Lowe, D., Ryder, J., Leigh, R., Dorsey, J. R., and McFiggans, G.: Modelling multi-phase halogen chemistry in the coastal marine boundary layer: investigation of the relative importance of local chemistry vs. long-range transport, Atmos. Chem. Phys., 11, 979-994, https://doi.org/10.5194/acp-11-979-2011, 2011.

Lowe, D., Archer-Nicholls, S., Morgan, W., Allan, J., Utembe, S., Ouyang, B., Aruffo, E., Le Breton, M., Zaveri, R. A., Di Carlo, P., Percival, C., Coe, H., Jones, R., and McFiggans, G.: WRF-Chem model predictions of the regional impacts of $\mathrm{N}_{2} \mathrm{O}_{5}$ heterogeneous processes on night-time chemistry over north-western Europe, Atmos. Chem. Phys., 15, 1385-1409, https://doi.org/10.5194/acp-15-1385-2015, 2015.

Macintyre, H. L. and Evans, M. J.: Sensitivity of a global model to the uptake of $\mathrm{N}_{2} \mathrm{O}_{5}$ by tropospheric aerosol, Atmos. Chem. Phys., 10, 7409-7414, https://doi.org/10.5194/acp10-7409-2010, 2010.

Mao, J., Fan, S., Jacob, D. J., and Travis, K. R.: Radical loss in the atmosphere from $\mathrm{Cu}-\mathrm{Fe}$ redox coupling in aerosols, Atmos. Chem. Phys., 13, 509-519, https://doi.org/10.5194/acp-13-5092013, 2013. 
Mogili, P. K., Kleiber, P. D., Young, M. A., and Grassian, V. H.: Heterogeneous uptake of ozone on reactive components of mineral dust aerosol: an environmental aerosol reaction chamber study, J. Phys. Chem. A, 110, 13799-13807, 2006.

Moise, T., Talukdar, R., Frost, G., Fox, R., and Rudich, Y.: Reactive uptake of $\mathrm{NO}_{3}$ by liquid and frozen organics, J. Geophys. Res.Atmos., 107, AAC-6, https://doi.org/10.1029/2001JD000334, 2002.

Morgan, W. T., Ouyang, B., Allan, J. D., Aruffo, E., Di Carlo, P., Kennedy, O. J., Lowe, D., Flynn, M. J., Rosenberg, P. D., Williams, P. I., Jones, R., McFiggans, G. B., and Coe, H.: Influence of aerosol chemical composition on $\mathrm{N}_{2} \mathrm{O}_{5}$ uptake: airborne regional measurements in northwestern Europe, Atmos. Chem. Phys., 15, 973-990, https://doi.org/10.5194/acp-15-9732015, 2015.

Mozurkewich, M. and Calvert, J. G.: Reaction possibility of $\mathrm{N}_{2} \mathrm{O}_{5}$ on aqueous aerosols, J. Geophys. Res.-Atmos., 93, 1588915896, 1988.

Neubauer, D., Siegenthaler-Le Drian, C., Ferrachat, S., Bey, I., Lohmann, U., Stanelle, T., Frontoso, G., Stier, P., Schutgens, N., Schmidt, H., Rast, S., Schultz, M. G., Schroeder, S., Tegen, I., and Heinold, B.: The new version of the global aerosol-climate model ECHAM6-HAM: aerosol evaluation against observations and previous versions, Atmos. Chem. Phys., in preparation, 2018.

Nicolas, M., Ndour, M., Ka, O., D’Anna, B., and George, C.: Photochemistry of atmospheric dust: ozone decomposition on illuminated titanium dioxide, Environ. Sci. Technol., 43, 7437-7442, 2009.

Parrish, D. D., Millet, D. B., and Goldstein, A. H.: Increasing ozone in marine boundary layer inflow at the west coasts of North America and Europe, Atmos. Chem. Phys., 9, 1303-1323, https://doi.org/10.5194/acp-9-1303-2009, 2009.

Parrish, D., Lamarque, J.-F., Naik, V., Horowitz, L., Shindell, D., Staehelin, J., Derwent, R., Cooper, O., Tanimoto, H., VolzThomas, A., Gilge, S., Scheel, H.-E., Steinbacher, M., and Froehlich, M.: Long-term changes in lower tropospheric baseline ozone concentrations: comparing chemistry-climate models and observations at northern midlatitudes, J. Geophys. Res.-Atmos., 119, 5719-5736, 2014.

Pathak, R. K., Wu, W. S., and Wang, T.: Summertime $\mathrm{PM}_{2.5}$ ionic species in four major cities of China: nitrate formation in an ammonia-deficient atmosphere, Atmos. Chem. Phys., 9, 17111722, https://doi.org/10.5194/acp-9-1711-2009, 2009.

Platt, U., Perner, D., Harris, G., Winer, A., and Pitts Jr., J.: Observations of nitrous acid in an urban atmosphere by differential optical absorption, Nature, 285, 312-314, 1980.

Pöschl, U.: Atmospheric aerosols: composition, transformation, climate and health effects, Angew. Chem. Int. Edit., 44, 7520-7540, 2005.

Ravishankara, A.: Heterogeneous and multiphase chemistry in the troposphere, Science, 276, 1058-1065, 1997.

Remorov, R., Gershenzon, Y. M., Molina, L., and Molina, M.: Kinetics and mechanism of $\mathrm{HO}_{2}$ uptake on solid $\mathrm{NaCl}$, J. Phys. Chem. A, 106, 4558-4565, 2002.

Reus, M., Dentener, F., Thomas, A., Borrmann, S., Ström, J., and Lelieveld, J.: Airborne observations of dust aerosol over the North Atlantic Ocean during ACE 2: indications for heteroge- neous ozone destruction, J. Geophys. Res.-Atmos., 105, 1526315275, 2000.

Riedel, T. P., Bertram, T. H., Ryder, O. S., Liu, S., Day, D. A., Russell, L. M., Gaston, C. J., Prather, K. A., and Thornton, J. A.: Direct $\mathrm{N}_{2} \mathrm{O}_{5}$ reactivity measurements at a polluted coastal site, Atmos. Chem. Phys., 12, 2959-2968, https://doi.org/10.5194/acp12-2959-2012, 2012.

Riemer, N., Vogel, H., Vogel, B., Schell, B., Ackermann, I., Kessler, C., and Hass, H.: Impact of the heteorogenous hydrolysis of $\mathrm{N}_{2} \mathrm{O}_{5}$ on chemistry and nitrate formation in the lower troposhere under photosmog conditions, J. Geophys. Res., 108, 4144, https://doi.org/10.1029/2002JD002436, 2003.

Riemer, N., Vogel, H., Vogel, B., Anttila, T., Kiendler-Scharr, A., and Mentel, T.: Relative importance of organic coatings for the heterogeneous hydrolysis of $\mathrm{N}_{2} \mathrm{O}_{5}$ during summer in Europe, J. Geophys. Res.-Atmos., 114, D17307, https://doi.org/10.1029/2008JD011369, 2009.

Rudich, Y., Talukdar, R. K., Ravishankara, A., and Fox, R.: Reactive uptake of $\mathrm{NO}_{3}$ on pure water and ionic solutions, J. Geophys. Res.-Atmos., 101, 21023-21031, 1996.

Rudich, Y., Talukdar, R., and Ravishankara, A.: Multiphase chemistry of $\mathrm{NO}_{3}$ in the remote troposphere, J. Geophys. Res.-Atmos., 103, 16133-16143, 1998.

Saathoff, H., Naumann, K.-H., Riemer, N., Kamm, S., Möhler, O., Schurath, U., Vogel, H., and Vogel, B.: The loss of $\mathrm{NO}_{2}, \mathrm{HNO}_{3}$, $\mathrm{NO}_{3} / \mathrm{N}_{2} \mathrm{O}_{5}$, and $\mathrm{HO}_{2} / \mathrm{HOONO}_{2}$ on soot aerosol: a chamber and modeling study, Geophys. Res. Lett., 28, 1957-1960, 2001.

Sander, S. P., Friedl, R., Golden, D., Kurylo, M., Moortgat, G., Keller-Rudek, H., Wine, P., Ravishankara, A., Kolb, C., Molina, M. J., Finlayson-Pitts, B. J., Huie, R., and Orkin V. L.: Chemical kinetics and photochemical data for use in atmospheric studies: evaluation number 15, National Aeronautics and Space Administration, Jet Propulsion Laboratory, California Institute of Technology Pasadena, CA, 2006.

Sarwar, G., Simon, H., Bhave, P., and Yarwood, G.: Examining the impact of heterogeneous nitryl chloride production on air quality across the United States, Atmos. Chem. Phys., 12, 6455-6473, https://doi.org/10.5194/acp-12-6455-2012, 2012.

Sarwar, G., Simon, H., Xing, J., and Mathur, R.: Importance of tropospheric $\mathrm{ClNO}_{2}$ chemistry across the Northern Hemisphere, Geophys. Res. Lett., 41, 4050-4058, https://doi.org/10.1002/2014GL059962, 2014.

Schaap, M., Cuvelier, C., Hendriks, C., Bessagnet, B., Baldasano, J., Colette, A., Thunis, P., Karam, D., Fagerli, H., Graff, A., Kranenburg, R., Nyiri, A., Pay, M., Rouïl, L., Schulz, M., Simpson, D., Stern, R., Terrenoire, E., and Wind, P.: Performance of European chemistry transport models as function of horizontal resolution, Atmos. Environ., 112, 90-105, https://doi.org/10.1016/j.atmosenv.2015.04.003, 2015.

Schultz, M. G., Akimoto, H., Bottenheim, J., Buchmann, B., Galbally, I. E., Gilge, S., Helmig, D., Koide, H., Lewis, A. C., Novelli, P. C., Plass-Duelmer, C., Ryerson, T. B., Steinbacher, M., Steinbrecher, R., Tarasova, O., Torseth, K., Thouret, V., and Zellweger, C.: The Global Atmosphere Watch reactive gases measurement network, Elementa-Science of the Anthropocene, 3, https://doi.org/10.12952/journal.elementa.000067, 2015.

Schultz, M. G., Schröder, S., Lyapina, O., Cooper, O. R., Galbally, I., Petropavlovskikh, I., von Schneidemesser, E., Tanimoto, H., Elshorbany, Y., Naja, M., Seguel, R. J., Dauert, U., 
Eckhardt, P., Feigenspan, S., Fiebig, M., Hjellbrekke, A.-G., Hong, Y.-D., Kjeld, P. C., Koide, H., Lear, G., Tarasick, D., Ueno, M., Wallasch, M., Baumgardner, D., Chuang, M.-T., Gillett, R., Lee, M., Molloy, S., Moolla, R., Wang, T., Sharps, K., Adame, J. A., Ancellet, G., Apadula, F., Artaxo, P., Barlasina, M. E., Bogucka, M., Bonasoni, P., Chang, L., Colomb, A., Cuevas-Agullo, E., Cupeiro, M., Degorska, A., Ding, A., Fröhlich, M., Frolova, M., Gadhavi, H., Gheusi, F., Gilge, S., Gonzalez, M. Y., Gros, V., Hamad, S. H., Helmig, D., Henriques, D., Hermansen, O., Holla, R., Hueber, J., Im, U., Jaffe, D. A., Komala, N., Kubistin, D., Lam, K.-S., Laurila, T., Lee, H., Levy, I., Mazzoleni, C., Mazzoleni, L. R., McClure-Begley, A., Mohamad, M., Murovec, M., NavarroComas, M., Nicodim, F., Parrish, D., Read, K. A., Reid, N., Ries, L., Saxena, P., Schwab, J. J., Scorgie, Y., Senik, I., Simmonds, P., Sinha, V., Skorokhod, A. I., Spain, G., Spangl, W., Spoor, R., Springston, S. R., Steer, K., Steinbacher, M., Suharguniyawan, E., Torre, P., Trickl, T., Weili, L., Weller, R., Xiaobin, X., Xue, L., and Zhiqiang, M.: Tropospheric Ozone Assessment Report: database and metrics data of global surface ozone observations, Elementa-Science of the Anthropocene, 5, 58-Article, https://doi.org/10.1525/elementa.244, 2017a.

Schultz, M. G., Schröder, S., Lyapina, O., Cooper, O. R., Galbally, I., Petropavlovskikh, I., von Schneidemesser, E., Tanimoto, H., Elshorbany, Y., Naja, M., Seguel, R. J., Dauert, U., Eckhardt, P., Feigenspan, S., Fiebig, M., Hjellbrekke, A.G., Hong, Y.-D., Kjeld, P. C., Koide, H., Lear, G., Tarasick, D., Ueno, M., Wallasch, M., Baumgardner, D., Chuang, M.-T., Gillett, R., Lee, M., Molloy, S., Moolla, R., Wang, T., Sharps, K., Adame, J. A., Ancellet, G., Apadula, F., Artaxo, P., Barlasina, M. E., Bogucka, M., Bonasoni, P., Chang, L., Colomb, A., Cuevas-Agulló, E., Cupeiro, M., Degorska, A., Ding, A., Fröhlich, M., Frolova, M., Gadhavi, H., Gheusi, F., Gilge, S., Gonzalez, M. Y., Gros, Valérie, Hamad, S. H., Helmig, D., Henriques, D., Hermansen, O., Holla, R., Hueber, J., Im, U., Jaffe, D. A., Komala, N., Kubistin, D., Lam, K.-S., Laurila, T., Lee, H., Levy, I., Mazzoleni, C., Mazzoleni, L. R., McClureBegley, A., Mohamad, M., Murovec, M., Navarro-Comas, M., Nicodim, F., Parrish, D., Read, K. A., Reid, N., Ries, L., Saxena, P., Schwab, J. J., Scorgie, Y., Senik, I., Simmonds, P., Sinha, V., Skorokhod, A., I., Spain, G., Spangl, W., Spoor, R., Springston, S. R., Steer, K., Steinbacher, M., Suharguniyawan, E., Torre, P., Trickl, T., Weili, L., Weller, R., Xu, X., Xue, L., and Zhiqiang, M.: Tropospheric Ozone Assessment Report, links to Global surface ozone datasetsx, PANGAEA, available at: https://doi.org/10.1594/PANGAEA.876108, 2017b.

Schultz, M. G., Stadtler, S., Schröder, S., Taraborrelli, D., Franco, B., Krefting, J., Henrot, A., Ferrachat, S., Lohmann, U., Neubauer, D., Siegenthaler-Le Drian, C., Wahl, S., Kokkola, H., Kühn, T., Rast, S., Schmidt, H., Stier, P., Kinnison, D., Tyndall, G. S., Orlando, J. J., and Wespes, C.: The Chemistry Climate Model ECHAM6.3-HAM2.3-MOZ1.0, Geosci. Model Dev. Discuss., https://doi.org/10.5194/gmd-2017-191, in review, 2017.

Schwartz, S. E.: Mass-transport considerations pertinent to aqueous phase reactions of gases in liquid-water clouds, in: Chemistry of Multiphase Atmospheric Systems, Springer, 415-471, 1986.

Seinfeld, J. H. and Pandis, S. N.: Atmosperic Chemistry and Physics: From Air Pollution to Climate Change, John Wiley and Sons, 2012.
Sillman, S., Logan, J., and Wofsy, S.: The sensitivity of ozone to nitrogen oxides and hydrocarbons in regional ozone episodes, J. Geophys. Res., 95, 1837-1851, 1990.

Simpson, D. and Stadtler, S.: Results from Stadtler et al 2018 Atmos. Chem. Phys.: Ozone impacts of gasaerosol uptake, EUDAT, https://doi.org/10.23728/b2share. 45d9c632b8a645309435ea33394b6cce, last access: 28 February 2018 .

Simpson, D., Winiwarter, W., Börjesson, G., Cinderby, S., Ferreiro, A., Guenther, A., Hewitt, C. N., Janson, R., Khalil, M. A. K., Owen, S., Pierce, T. E., Puxbaum, H., Shearer, M., Skiba, U., Steinbrecher, R., Tarrasón, L., and Öquist, M. G.: Inventorying emissions from Nature in Europe, J. Geophys. Res., 104, 8113-8152, 1999.

Simpson, D., Butterbach-Bahl, K., Fagerli, H., Kesik, M., Skiba, U., and Tang, S.: Deposition and emissions of reactive nitrogen over European forests: a modelling study, Atmos. Environ., 40, 57125726, https://doi.org/10.1016/j.atmosenv.2006.04.063, 2006a.

Simpson, D., Fagerli, H., Hellsten, S., Knulst, J. C., and Westling, O.: Comparison of modelled and monitored deposition fluxes of sulphur and nitrogen to ICP-forest sites in Europe, Biogeosciences, 3, 337-355, https://doi.org/10.5194/bg-3-3372006, 2006b.

Simpson, D., Benedictow, A., Berge, H., Bergström, R., Emberson, L. D., Fagerli, H., Flechard, C. R., Hayman, G. D., Gauss, M., Jonson, J. E., Jenkin, M. E., Nyíri, A., Richter, C., Semeena, V. S., Tsyro, S., Tuovinen, J.-P., Valdebenito, Á., and Wind, P.: The EMEP MSC-W chemical transport model - technical description, Atmos. Chem. Phys., 12, 7825-7865, https://doi.org/10.5194/acp-12-7825-2012, 2012.

Simpson, D., Arneth, A., Mills, G., Solberg, S., and Uddling, J.: Ozone - the persistent menace; interactions with the $\mathrm{N}$ cycle and climate change, Curr. Opin. Env. Sust., 9-10, 9-19, https://doi.org/10.1016/j.cosust.2014.07.008, 2014.

Simpson, D., Tsyro, S., and Wind, P.: Updates to the EMEP/MSCW model, in: Transboundary Particulate Matter, Photo-Oxidants, Acidifying and Eutrophying Components, Status Report 1/2015, 129-138, The Norwegian Meteorological Institute, Oslo, Norway, 2015.

Simpson, D., Bergström, R., Imhof, H., and Wind, P.: Updates to the EMEP/MSC-W model, 2016-2017, in: Transboundary Particulate Matter, Photo-Oxidants, Acidifying and Eutrophying Components, EMEP Status Report 1/2016, 115-122, The Norwegian Meteorological Institute, Oslo, Norway, 2017.

Solomon, S.: Stratospheric ozone depletion: a review of concepts and history, Rev. Geophys., 37, 275-316, 1999.

Solomon, S., Garcia, R. R., Rowland, F. S., and Wuebbles, D. J.: On the depletion of Antarctic ozone, Nature, 321, 755-758, 1986.

Stadtler, S.: Heterogeneous $\mathrm{N}_{2} \mathrm{O}_{5}$ Chemistry in the AerosolChemistry-Climate Model ECHAM6-HAMMOZ, Master's thesis, University of Bonn, 2015.

Stein, O., Flemming, J., Inness, A., Kaiser, J. W., and Schultz, M. G.: Global reactive gases forecasts and reanalysis in the MACC project, J. Integr. Environ. Sci., 9, 57-70, 2012.

Stevens, B., Giorgetta, M., Esch, M., Mauritsen, T., Crueger, T., Rast, S., Salzmann, M., Schmidt, H., Bader, J., Block, K., Brokopf, R., Fast, I., Konne, S., Kornblueh, L., Lohnmann, U., Pincus, R., Reichler, T., and Roeckner, E.: Atmospheric com- 
ponent of the MPI-M Earth System Model: ECHAM6, J. Adv. Model. Earth Sy., 5, 146-172, 2013.

Stone, D., Evans, M. J., Walker, H., Ingham, T., Vaughan, S., Ouyang, B., Kennedy, O. J., McLeod, M. W., Jones, R. L., Hopkins, J., Punjabi, S., Lidster, R., Hamilton, J. F., Lee, J. D., Lewis, A. C., Carpenter, L. J., Forster, G., Oram, D. E., Reeves, C. E., Bauguitte, S., Morgan, W., Coe, H., Aruffo, E., Dari-Salisburgo, C., Giammaria, F., Di Carlo, P., and Heard, D. E.: Radical chemistry at night: comparisons between observed and modelled $\mathrm{HO}_{x}, \mathrm{NO}_{3}$ and $\mathrm{N}_{2} \mathrm{O}_{5}$ during the RONOCO project, Atmos. Chem. Phys., 14, 1299-1321, https://doi.org/10.5194/acp14-1299-2014, 2014.

Taketani, F., Kanaya, Y., and Akimoto, H.: Kinetics of heterogeneous reactions of $\mathrm{HO}_{2}$ radical at ambient concentration levels with $\left(\mathrm{NH}_{4}\right)_{2} \mathrm{SO}_{4}$ and $\mathrm{NaCl}$ aerosol particles, J. Phys. Chem. A, 112, 2370-2377, 2008.

Taraborrelli, D., Lawrence, M. G., Butler, T. M., Sander, R., and Lelieveld, J.: Mainz Isoprene Mechanism 2 (MIM2): an isoprene oxidation mechanism for regional and global atmospheric modelling, Atmos. Chem. Phys., 9, 2751-2777, https://doi.org/10.5194/acp-9-2751-2009, 2009.

Thornton, J. and Abbatt, J. P.: Measurements of $\mathrm{HO}_{2}$ uptake to aqueous aerosol: mass accommodation coefficients and net reactive loss, J. Geophys. Res.-Atmos., 110, D08309, https://doi.org/10.1029/2004JD005402, 2005.

Thornton, J. A., Braban, C. F., and Abbatt, J. P.: $\mathrm{N}_{2} \mathrm{O}_{5}$ hydrolysis on sub-micron organic aerosols: the effect of relative humidity, particle phase, and particle size, Phys. Chem. Chem. Phys., 5, 4593-4603, 2003.

Thornton, J. A., Jaeglé, L., and McNeill, V. F.: Assessing known pathways for $\mathrm{HO}_{2}$ loss in aqueous atmospheric aerosols: regional and global impacts on tropospheric oxidants, J. Geophys. Res.Atmos., 113, D05303, https://doi.org/10.1029/2007JD009236, 2008.

Tie, X., Brasseur, G., Emmons, L., Horowitz, L., and Kinnison, D.: Effects of aerosols on tropospheric oxidants: a global model study, J. Geophys. Res.-Atmos., 106, 22931-22964, 2001.

Tie, X., Emmons, L., Horowitz, L., Brasseur, G., Ridley, B., Atlas, E., Stround, C., Hess, P., Klonecki, A., Madronich, S., Talbot, R., and Dibb, J.: Effect of sulfate aerosol on tropospheric $\mathrm{NO}_{x}$ and ozone budgets: Model simulations and TOPSE evidence, J. Geophys. Res.-Atmos., 108, https://doi.org/10.1029/2001JD001508, 2003.

Tilgner, A., Majdik, Z., Sehili, A., Simmel, M., Wolke, R., and Herrmann, H.: SPACCIM: Simulations of the multiphase chemistry occurring in the FEBUKO hill cap cloud experiments, Atmos. Environ., 39, 4389-4401, 2005.

Tørseth, K., Aas, W., Breivik, K., Fjæraa, A. M., Fiebig, M., Hjellbrekke, A. G., Lund Myhre, C., Solberg, S., and Yttri, K. E.: Introduction to the European Monitoring and Evaluation Programme (EMEP) and observed atmospheric composition change during 1972-2009, Atmos. Chem. Phys., 12, 5447-5481, https://doi.org/10.5194/acp-12-5447-2012, 2012.

Tsyro, S., Aas, W., Soares, J., Sofiev, M., Berge, H., and Spindler, G.: Modelling of sea salt concentrations over Europe: key uncertainties and comparison with observations, Atmos. Chem. Phys., 11, 10367-10388, https://doi.org/10.5194/acp-11-103672011, 2011.
Underwood, G., Song, C., Phadnis, M., Carmichael, G., and Grassian, V.: Heterogeneous reactions of $\mathrm{NO}_{2}$ and $\mathrm{HNO}_{3}$ on oxides and mineral dust: a combined laboratory and modeling study, J. Geophys. Res.-Atmos., 106, 18055-18066, 2001.

Usher, C. R., Michel, A. E., and Grassian, V. H.: Reactions on mineral dust, Chem. Rev., 103, 4883-4940, 2003.

van Donkelaar, A., Martin, R. V., Brauer, M., and Boys, B. L.: Use of satellite observations for long-term exposure assessment of global concentrations of fine particulate matter, Environ. Health Persp., 123, 135-143, 2015.

Van Vuuren, D. P., Edmonds, J., Kainuma, M., Riahi, K., Thomson, A., Hibbard, K., Hurtt, G. C., Kram, T., Krey, V., Lamarque, J.-F., Masui, T., Meinhausen, M., Nakicenovic, N., Smith, S. J., and Rose, S. K.: The representative concentration pathways: an overview, Climatic Change, 109, 5, https://doi.org/10.1007/s10584-011-0148-z, 2011.

Verwer, J. and Simpson, D.: Explicit methods for stiff ODEs from atmospheric chemistry, Appl. Numer. Math., 18, 413-430, 1995.

Verwer, J. G., Blom, J. G., Van Loon, M., and Spee, E. J.: A comparison of stiff ODE solvers for atmospheric chemistry problems, Atmos. Environ., 30, 49-58, 1996.

Vieno, M., Dore, A. J., Bealey, W. J., Stevenson, D. S., and Sutton, M. A.: The importance of source configuration in quantifying footprints of regional atmospheric sulphur deposition, Sci. Total Environ., 408, 985-995, https://doi.org/10.1016/j.scitotenv.2009.10.048, 2010.

Vieno, M., Heal, M. R., Hallsworth, S., Famulari, D., Doherty, R. M., Dore, A. J., Tang, Y. S., Braban, C. F., Leaver, D., Sutton, M. A., and Reis, S.: The role of long-range transport and domestic emissions in determining atmospheric secondary inorganic particle concentrations across the UK, Atmos. Chem. Phys., 14, 8435-8447, https://doi.org/10.5194/acp-14-8435-2014, 2014.

Vignati, E., Wilson, J., and Stier, P.: M7: An efficient size-resolved aerosol microphysics module for large-scale aerosol transport models, J. Geophys. Res.-Atmos., 109, https://doi.org/10.1029/2003JD004485, 2004.

Vinken, G. C. M., Boersma, K. F., Jacob, D. J., and Meijer, E. W.: Accounting for non-linear chemistry of ship plumes in the GEOS-Chem global chemistry transport model, Atmos. Chem. Phys., 11, 11707-11722, https://doi.org/10.5194/acp-11-117072011, 2011.

von Glasow, R., Lawrence, M. G., Sander, R., and Crutzen, P. J.: Modeling the chemical effects of ship exhaust in the cloudfree marine boundary layer, Atmos. Chem. Phys., 3, 233-250, https://doi.org/10.5194/acp-3-233-2003, 2003.

Wagner, N., Riedel, T., Young, C., Bahreini, R., Brock, C., Dubé, W., Kim, S., Middlebrook, A., Öztürk, F., Roberts, J. M., Russo, R., Sive, B., Swarthout, R., Thornton, J. A., VandenBoer, T. C., Zhou, Y., and Brown, S. S.: $\mathrm{N}_{2} \mathrm{O}_{5}$ uptake coefficients and nocturnal $\mathrm{NO}_{2}$ removal rates determined from ambient wintertime measurements, J. Geophys. Res.-Atmos., 118, 9331-9350, 2013.

Wahner, A., Mentel, T. F., Sohn, M., and Stier, J.: Heterogeneous reaction of $\mathrm{N}_{2} \mathrm{O}_{5}$ on sodium nitrate aerosol, J. Geophys. Res.Atmos., 103, 31103-31112, 1998.

Wang, T., Tham, Y. J., Xue, L., Li, Q., Zha, Q., Wang, Z., Poon, S. C., Dubé, W. P., Blake, D. R., Louie, P. K., Luk, C. W. Y., Tsui, W., and Brown, S. S.: Observations of nitryl chloride and modeling its source and effect on ozone in the planetary 
boundary layer of southern China, J. Geophys. Res.-Atmos., 121, 2476-2489, 2016.

Weiss, A. and Norman, J. M.: Partitioning solar-radiation into direct and diffuse, visible and near-infrared components, Agr. Forest Meteorol., 34, 205-213, https://doi.org/10.1016/01681923(85)90020-6, 1985.

Whalley, L. K., Stone, D., George, I. J., Mertes, S., van Pinxteren, D., Tilgner, A., Herrmann, H., Evans, M. J., and Heard, D. E.: The influence of clouds on radical concentrations: observations and modelling studies of $\mathrm{HO}_{x}$ during the Hill Cap Cloud Thuringia (HCCT) campaign in 2010, Atmos. Chem. Phys., 15, 3289-3301, https://doi.org/10.5194/acp-15-3289-2015, 2015.

Wild, O. and Akimoto, H.: Intercontinental transport of ozone and its precursors in a three-dimensional global CTM, J. Geophys. Res.-Atmos., 106, 27729-27744, 2001.

Wild, O., Fiore, A. M., Shindell, D. T., Doherty, R. M., Collins, W. J., Dentener, F. J., Schultz, M. G., Gong, S., MacKenzie, I. A., Zeng, G., Hess, P., Duncan, B. N., Bergmann, D. J., Szopa, S., Jonson, J. E., Keating, T. J., and Zuber, A.: Modelling future changes in surface ozone: a parameterized approach, Atmos. Chem. Phys., 12, 2037-2054, https://doi.org/10.5194/acp12-2037-2012, 2012.
Wu, S., Mickley, L. J., Jacob, D. J., Logan, J. A., Yantosca, R. M., and Rind, D.: Why are there large differences between models in global budgets of tropospheric ozone?, J. Geophys. Res.-Atmos., 112, D05302, https://doi.org/10.1029/2006JD007801, 2007.

Yang, X., Pyle, J. A., and Cox, R. A.: Sea salt aerosol production and bromine release: role of snow on sea ice, Geophys. Res. Lett., 35, 8911-8949, https://doi.org/10.1029/2008GL034536, 2008.

Zhang, K., O’Donnell, D., Kazil, J., Stier, P., Kinne, S., Lohmann, U., Ferrachat, S., Croft, B., Quaas, J., Wan, H., Rast, S., and Feichter, J.: The global aerosol-climate model ECHAM-HAM, version 2: sensitivity to improvements in process representations, Atmos. Chem. Phys., 12, 8911-8949, https://doi.org/10.5194/acp-12-8911-2012, 2012. 